\title{
Managing coral reef fish community biomass is a priority for biodiversity conservation in Madagascar
}

\author{
Tim R. McClanahan ${ }^{1, *}$, Catherine Jadot ${ }^{2}$ \\ ${ }^{1}$ Wildlife Conservation Society, Marine Programs, Bronx, NY 10460, USA \\ ${ }^{2}$ ES Caribbean, Venice, FL 34293, USA
}

\begin{abstract}
Elucidating factors that influence natural resources and diversity can assist managing species and their ecological functions. Key management options include protecting unique locations or implementing restrictions that more broadly protect ecological attributes and their services. To evaluate these 2 options, we examined 23 fish families in 152 unique sites in the Western and Northern Madagascar Ecoregion to test for spatial aggregation, environmental, habitat, and human influences on the fish communities. We found that there were 10 distinct communities of fish and that they were widely distributed in the region. Biomass and diversity were closely associated with the community types and showed weak spatial aggregation and environmental and market influences. Further, fishable biomass was only weakly positively associated with habitat characteristics of depth and soft coral cover and negatively associated with erect algae $\left(\mathrm{R}^{2}=0.06\right)$. Biomass was the strongest predictor of number of species whereas associations with light and hard coral cover were weak and median sea surface temperature (SST) and water depth had the weakest influences (all variable $\mathrm{R}^{2}=0.41$ ). Given the weak spatial aggregation, environmental influences, high spatial and species variability, we suggest that there are few conservation priority locations. Consequently, for ecological representation and function there is a need for broad-scale spatial management that captures this heterogeneity and maintains reef fish biomass. The status of reefs in this ecoregion was fair with $\sim 65 \%$ of the study sites having biomass $>600 \mathrm{~kg} \mathrm{ha}^{-1}$.
\end{abstract}

KEY WORDS: Sustainability · Priority setting · Biodiversity conservation · Island biogeography · Ecosystem based management $\cdot$ Marine spatial planning $\cdot$ Indian Ocean $\cdot$ Africa

\section{INTRODUCTION}

Coral reef fish communities are structured at a number of scales by historical, environmental, ecological, and human influences (Pellessier et al. 2014, MacNeil et al. 2015, McClanahan et al. 2015, Mellin et al. 2016b). The roles that these forces play in influencing community composition, biomass, and diversity are increasingly being understood on large regional and global scales (Jennings et al. 1995, Newman et al. 2006, Mellin et al. 2010, Parravicini et al. 2013, McClanahan 2015a). This information not only provides insights

\footnotetext{
${ }^{*}$ Corresponding author: tmcclanahan@wcs.org
}

for understanding the ecology of reef fishes but also for planning and implementing conservation and management of reef communities (Parravicini et al. 2014, Mouillot et al. 2016). For example, identifying and managing fish communities with the properties of high biomass and diversity can increase the resilience of reefs threatened by local and global human pressures (McClanahan et al. 2011, Graham et al. 2015). Conversely, identifying communities with low biomass and number of species suggests the need for greater restrictive management to prevent declining yields and ecological degradation.

() The authors 2017. Open Access under Creative Commons by Attribution Licence. Use, distribution and reproduction are unrestricted. Authors and original publication must be credited. 
The biomass and diversity of reef fishes appear to play important roles in maintaining reef structure and processes of coral reefs (Burkepile \& Hay 2008, McClanahan et al. 2011, Thibaut \& Connolly 2013, Chong-Seng et al. 2014). Factors such as heavy fishing and climate change have the potential to erode ecological states and processes. Consequently, evaluating biomass and diversity and managing for levels that maintain ecological stability and processes are central goals of this applied research (Mellin et al. 2014, Plass-Johnson et al. 2016). Moreover, determining how fish communities change along human and environmental gradients is an initial step in prioritizing management. Once these underlying forces are understood, the priorities and means to successfully manage diversity can be determined. Biodiversity assessments are particularly useful in areas where people are highly dependent on diverse natural resources and utilize this diversity.

In this study we examined coral reef fish communities, biomass, and diversity in most of the major regions of Madagascar and the associated islands containing coral reefs, known as the Western and Northern Madagascar Ecoregion (WNME) (Spalding et al. 2007). The main questions asked were (1) are there distinct coral reef fish communities, what is their composition, and where are they distributed; (2) are these communities and their biomass and diversity unevenly distributed in space; (3) what is the relationship between biomass and local number of species, and (4) how are communities influenced by benthic cover, environmental variables, and human influence? Then, based on this assessment, we evaluated the factors controlling the communities and considered the management needed to maintain this diversity. These basic ecological/biogeographic questions were addressed in a region with little previous coral reef ecological research (McClanahan et al. 2009, Harris et al. 2010, Vincent et al. 2011).

\section{MATERIALS AND METHODS}

\section{Study sites}

The focus of this study is the WNME, which is one of 4 ecoregions within the social-political affiliation known as the Southwest Indian Ocean (SWIO). The WNME ecoregion extends across 14 degrees of latitude and provides a natural geographic and environmental gradient (McClanahan et al. 2009, Grove et al. 2013, Maina et al. 2013). Four regions around
Madagascar were surveyed, as well as 3 volcanic islands of the archipelago, namely Grande Comore, Anjuan Island, and Mayotte. Madagascar, the fourth largest island in the world, has a coastline of $\sim 5000 \mathrm{~km}$ and an estimated reef area of $\sim 12600 \mathrm{~km}^{2}$. Additionally, the 4 main inhabited islands northwest of Madagascar have a total reef area of $430 \mathrm{~km}^{2}$ (Gabrié et al. 2000, Obura 2012). Coral reefs are mainly developed on the west coast, from Androka in the South to Antsiranana in the North, while reefs on the northeastern coast occur from the Cap of Ambre (Antsiranana) to Toamasina (Fig. 1). Mayotte is the geologically oldest island and has a well-developed barrier reef, whereas the other islands are more recent and the carbonate fringing reefs are more limited in size and distribution. Malagasy and Comorian people are heavily reliant on natural resources and therefore vulnerable to declines in production, particularly where climates are dry and agricultural production low. Consequently, good fisheries and protected area management may be expected to maintain high production and the stability of this important natural resource (Muthiga et al. 2000, Bruggemann et al. 2012, Le Manach et al. 2012, Barnes-Mauthe et al. 2013, Cinner et al. 2013).

\section{Field methods}

We compiled a large set of fish community data ( $\mathrm{n}=384$ samples, i.e. site $\times$ time, from 152 unique sites) collected on coral reefs between 2006 and 2015 by the 2 authors and a third observer. During each survey fish censuses were undertaken in $500 \mathrm{~m}^{2}$ belt transect replicates using 2 methods and multiple passes through the belt (McClanahan et al. 2007). During the first pass individual fish were identified to the family and sizes estimated and placed into $10 \mathrm{~cm}$ size interval classes. During subsequent passes individuals in a smaller group of pre-selected families (marked with an asterisk in the following list) were identified to the species level and counted. Fish families counted included the Acanthuridae*, Aulostomidae, Balistidae*, Carangidae, Chaetodontidae*, Diodontidae*, Fistularidae, Haemulidae, Holocentridae, Labridae*, Lethrinidae, Lutjanidae, Muraenidae, Mullidae, Pempheridae, Pinguipedidae, Pomacanthidae*, Pomacentridae*, Scaridae*, Serranidae, Scorpaenidae, Siganidae, and Sphyraenidae and an 'others' category for individuals not in these families. The Monacanthidae* were identified to the species level but were placed in the 'others' category for biomass estimates. Ecological function was the primary 


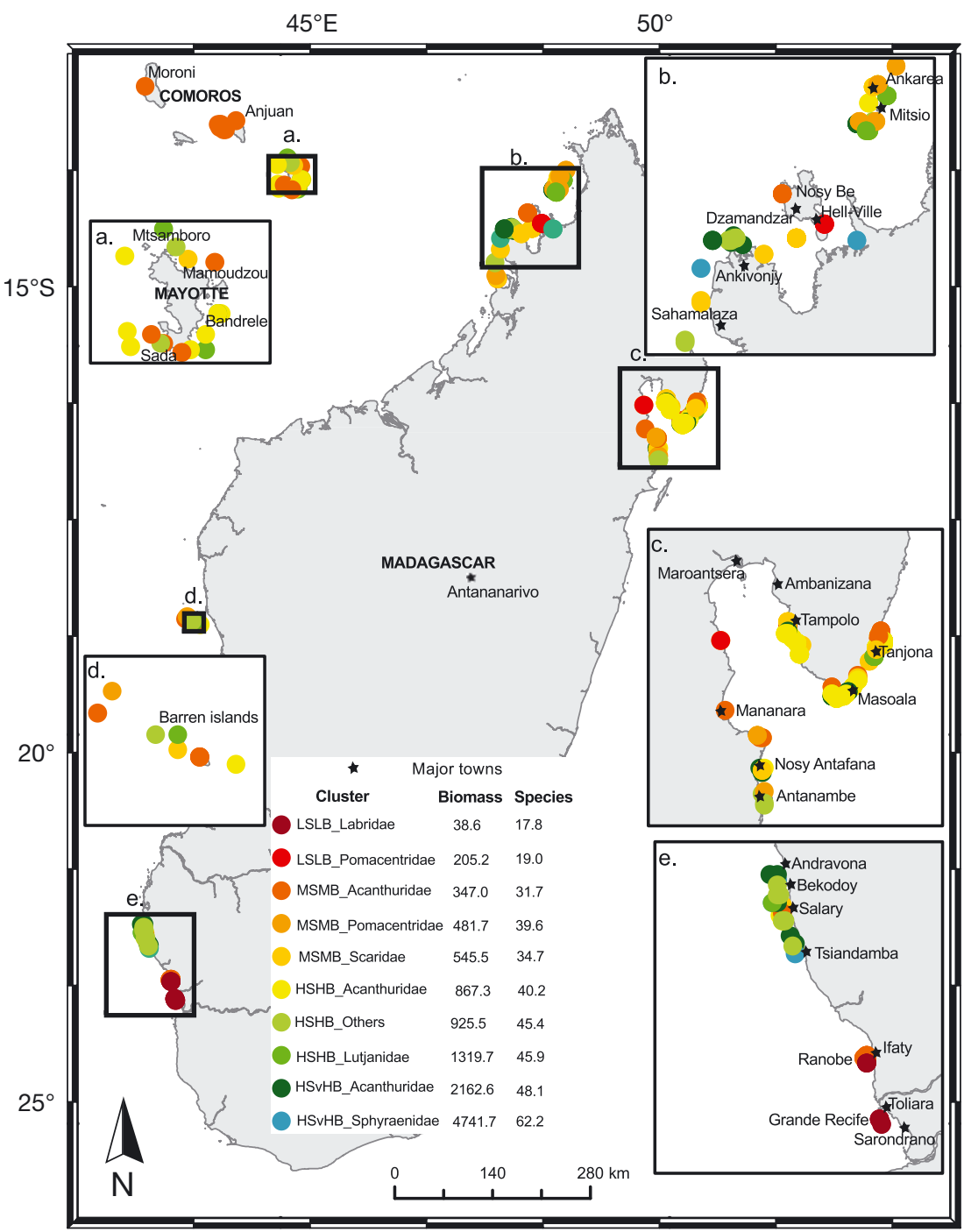

Fig. 1. Study sites for a survey of coral reef fish communities in the Western and Northern Madagascar Ecoregion (WNME) and the distribution of the 10 fish family cluster groups identified, listed in order from lowest (red) to highest biomass (blue), showing values for biomass $\left(\mathrm{kg} \mathrm{ha}^{-1}\right)$ and number of species (per $500 \mathrm{~m}^{2}$ ). Fish cluster groups were given names based on 3 levels of species richness (LS: low; MS: moderate; HS: high), 4 levels of biomass (LB: low; MB: moderate; HB: high; vHB: very high), and the dominant fish family by biomass (see Table 2)

focus of this study and therefore the Scaridae and Labridae were treated as unique rather than subfamilies, as scarids are grazers/detritivores while labrids are carnivores (Westneat et al. 2005). The midpoint of the fish size classes were used to estimate the wet mass of each size class based on established length-weight relationships for each family and summed across all size classes to get a family wet weight estimate (McClanahan \& Kaunda-Arara 1996). The sum of all size classes and families were used to estimate the total wet mass and values were converted to a per hectare unit for comparison with other field studies. The fishable biomass, a useful measure of the state of the reef, was estimated by removing damselfish and all fish $<10 \mathrm{~cm}$ in body size. Pairs of observers were compared for differences in their biomass estimates when they were sampled in the same locations but no significant differences were found (the lead author versus the 2 other observers: $t=0.26$, $\mathrm{n}=26$ and $t=1.27, \mathrm{n}=16$ ).

Benthic cover and depth. The depth of each site was estimated using a depth gauge. The bottom cover was estimated using the line intercept transects (LIT) method. Transects were laid out haphazardly onto the reef and draped to follow the contour of the reef. All hard corals $(>3 \mathrm{~cm})$ intercepting transects were identified to the genus level, and species level when possible, and measured to the nearest centimeter using a flexible tape measure. The absolute coral cover (\%) was estimated as the proportion of total length of all coral taxa over all benthic categories. No bottom complexity data were collected.

Environmental and human influence variables. Sea surface temperature data were accessed from the CoRTAD environmental satellite database (www.nodc.noaa.gov/sog/ cortad/), which is collected weekly at $4-\mathrm{km}$ resolution and we used the data from 1982 to 2015. Light $\left(\mathrm{E} \mathrm{m}^{-2}\right.$ $\mathrm{d}^{-1}$ ) and 2 water quality variables, chlorophyll a $\left(\mathrm{mg} \mathrm{m}^{-3}\right)$ and total suspended solids concentration $\left(\mathrm{g} \mathrm{m}^{-3}\right)$, were obtained from the COASTCOLOUR project (www.coastcolour.org/). The European Space Agency's GlobColor data were used rather than MODIS, SeaWIFS, or MERIS because it uses multiples sensors that average out errors from individual sensors. Therefore, it reduces the overall data variability and uncertainties, such as those caused by bottom reflectance. In total 16 water quality, light, and temperature-derived variables were calculated for the period 1982-2012 in order to get long-term average estimates for the sites. The 16 variables were evalu- 
ated for autocorrelation before deciding on 7 distinct variables for further analyses (Fig. S1 in the Supplement at www.int-res.com/articles/suppl/m580p169_ supp.pdf). The 7 chosen variables had low correlations with other variables and are known to be influential in ecological processes. The final variables included median photosynthetically active radiation (PAR), total suspended solids (TSS), median chlorophyll $a$ and, from the temperature time series, SST median, SST standard deviation, SST kurtosis, and SST skewness.

A human influence metric was developed based on human population density and distance to nearest markets (Brewer et al. 2013). Population data were derived from the Euclidean distance of sites to the nearest town and the populations of the town were added for each record. We used population data from the Gridded Population of the World database (http:// sedac.ciesin.columbia.edu/plue/cenguide.html, retrieved Dec 15, 2013). Human influence was calculated with the following formula:

$$
\begin{gathered}
\text { Human influence }= \\
\log _{\mathrm{e}}\left(\frac{1+\text { human count at market }}{(1+\text { distance from market to the reef })^{2}}\right)
\end{gathered}
$$

\section{Data analyses}

Analysis included collating the multiple sources of data, evaluating and testing for similarities among sites, the relationships between biomass, diversity, benthic cover, depth, human influence and satellitebased environmental data (Table 1). Replication for these analyses differed because of differences in measurements made or available among sites and, in some cases, pooling of sites. Of the total of 384 replicates, 374 had all environmental variables measured in the field or from satellites, biomass was measured at 337 replicates, and data on number of species was collected in 287 replicates. Numbers of species per $500 \mathrm{~m}^{2}$ was found to be a good proxy of local diversity at larger scales of sampling and is therefore used here as an indicator of local diversity (McClanahan 1997). For some environmental analyses, replicates sampled in nearly the same place over time were pooled and this reduced total number of replicates to 152 .

The fish community was analyzed using similarity and cluster analysis techniques. A hierarchical cluster analysis was performed on biomass values of 23 fish families and an others group that pooled all other species. Sites similarities were based on the BrayCurtis similarity index and clustered using hierarchi-

Table 1. Data source, analyses, and methods used to evaluate Western and Northern Madagascar Ecoregion (WNME) coral reef fish com-

\begin{tabular}{|c|c|c|}
\hline Data source & Analysis & Methods \\
\hline Fish community biomass from field surveys & Cluster analysis & $\begin{array}{l}\text { Bray-Curtis similarities, Ward variance } \\
\text { hierarchical clustering, similarity profile test } \\
\text { (SIMPRO) }\end{array}$ \\
\hline $\begin{array}{l}\text { Fish biomass and number of species } \\
\text { from field surveys }\end{array}$ & $\begin{array}{l}\text { Associations between biomass } \\
\text { and number of species }\end{array}$ & $\begin{array}{l}\text { Fit asymptote, logistic, Ricker and linear } \\
\text { equations }\end{array}$ \\
\hline $\begin{array}{l}\text { Fish community biomass, number of species } \\
\text { and benthic cover from field surveys; } \\
\text { environmental variables from satellite imagery; } \\
\text { human influence from global population grid }\end{array}$ & $\begin{array}{l}\text { Analysis of differences in cluster } \\
\text { groups }\end{array}$ & $\begin{array}{l}\text { ANOVA, Kruskal-Wallis, post-hoc Tukey } \\
\text { and Dunn's tests with Bonferroni adjustment } \\
\text { for multiple testing }\end{array}$ \\
\hline $\begin{array}{l}\text { Fish community biomass, number of species vs. } \\
\text { geographical variables of latitude and longitude }\end{array}$ & Spatial autocorrelation & Moran's $I$ \\
\hline $\begin{array}{l}\text { Fish biomass and number of species vs. } \\
\text { environmental and human influence variables }\end{array}$ & Linear/unimodal relationships & $\begin{array}{l}\text { Best-fit linear and second order polynomial } \\
\text { equations }\end{array}$ \\
\hline $\begin{array}{l}\text { Fish biomass, benthic cover vs. depth, human } \\
\text { influence and environmental variables }\end{array}$ & $\begin{array}{l}\text { Linear associations and variable } \\
\text { selection }\end{array}$ & $\begin{array}{l}\text { Forward stepwise regressions with AIC } \\
\text { and BIC stopping rules }\end{array}$ \\
\hline $\begin{array}{l}\text { Number of species vs. fish biomass, } \\
\text { benthic cover, depth, human influence and } \\
\text { environmental variables }\end{array}$ & $\begin{array}{l}\text { Linear associations and variable } \\
\text { selection }\end{array}$ & $\begin{array}{l}\text { Forward stepwise regressions with AIC } \\
\text { and BIC stopping rules }\end{array}$ \\
\hline $\begin{array}{l}\text { Fish community biomass vs. benthic cover and } \\
\text { environmental variables }\end{array}$ & Multivariate ordinations & $\begin{array}{l}\text { Canonical correspondence analysis, } \\
\text { variable selection via forward AIC stepwise }\end{array}$ \\
\hline
\end{tabular}
munities. AIC: Akaike information criterion; BIC: Bayesian information criterion 
cal Ward variance method ( $\mathrm{R}$ version 3.2.3, vegan package) with replicates pooled into unique sites. A similarity profile test was run to determine the number of significant clusters $(\alpha<0.05)$ (R package version 1.1; https://CRAN.R-project.org/package= clustsig). We used the similarity profile test (SIMPRO) profile analysis method that employs null hypothesis testing to detect structure in ecological communities (Clarke et al. 2008). The similarity profile analysis examines whether the similarities observed in the data are smaller or larger than those expected by chance based on objective measures. The clustering methods were done on raw and $\log _{\mathrm{e}}$ transformed biomass data. The analyses based on raw data are presented because family biomass data is a conservative representation of the fish community, as opposed to density, and a good reflection of functions and ecological impacts.

Fish cluster groups were given names based on 3 levels of species richness: (LS: low; MS: moderate; HS: high), 4 levels of biomass (LB: low; MB: moderate; HB: high; vHB: very high), and the dominant fish family (see Table 2). Cluster groups were compared for differences in abundance of families and environmental and human influence variables using Kruskal-Wallis and or ANOVA tests based on preliminary tests of normality of the data. Fish diversity $(D)$ was calculated as a modification of the Simpson's Index:

$$
D=1-\sum_{s=1}^{n}\left(n_{i} / N_{t}\right)^{2}
$$

where $D$ takes values from 0 to 1 representing the lowest and highest proportional diversity based on individuals (i) per species $(s), n_{i}$ is the number of individuals belonging to the $i$ th species and $N_{t}$ is the total number of individuals in the sample. Moran's $I$ index was used to test for spatial autocorrelation and spatial clustering of the biomass, numbers of species, and the community composition based on the 2 community structure axes. Moran's $I$ is used to test if distributions in space differ from random.

Fish biomass and benthic cover variables were evaluated for relationships with depth, satellitederived environmental, and human influence variables. First, evaluations of variable associations with numbers were explored to determine the appropriateness of linear stepwise regression analyses. To reduce autocorrelation and overfitting of models, the variables were first tested for colinearity using the variance inflation factor (VIF) before deciding on the final set of variables to be used in the regression analyses (Mansfield \& Helms 1982). We found that VIF values for groups of variables were low and ranged from 1.0 to 4.7 and therefore colinearity was not a problem for stepwise regression models. The one moderate VIF of 7.0 was found between median and skewness of SST but both variables were maintained because they represent important and different aspects of the temperature variability (Ateweberhan \& McClanahan 2010).

Fish biomass data were observed to have either linear or no clear relationships with variables but local number of species data were less clear and potentially unimodal. Consequently, number of species was tested for fits to linear and second order polynomial relationships for variables that might have unimodal relationships. Results indicated that any increases in fit to the polynomial were small $(<3.0 \%$ of variation) and therefore stepwise regression analyses were performed to compare the strengths of the fish biomass, environmental, benthic and human influence variables associations with number of species. Fish biomass was found to be the strongest variable associated with number of species. Therefore 2 analyses were done, one with biomass included and the second using the residuals of this biomass-number of species relationship.

Forward stepwise regression models used 2 stopping rules, namely inclusive (Akaike information criterion, AIC) and exclusive (Bayesian information criterion, BIC) methods. AIC is adequate or liberal. BIC is restrictive or conservative and useful for distinguishing associations versus possible causation that is a particularly common problem when evaluating number of species of reef fish (Mora \& Robertson 2005). Using both approaches allows for identifying and distinguishing among key variables and making stronger inferences about possible underlying causation. The BIC method penalizes for the addition of variables and therefore provides the simplest explanation but can also underfit model variables. AIC stopping rules are more inclusive, and can overfit models, but also have higher predictive ability (Burnham \& Anderson 2002). We also tested the same data using a multi-modeling approach by applying the dredge function implemented in the MuMIn package. We calculated AIC, corrected for small sample size (AICc) and the AICc-based relative importance weights $\left(w_{\mathrm{i}}\right)$ to assess the conditional probability of each model. Model averaging was applied to the models that were within 2 AICc units from the best model. The best model was the same as the stepwise approach and we therefore present only the simpler stepwise regression results.

Multivariate ordination of the sites and site descriptor variables was done using canonical corre- 
spondence analysis (CCA) to evaluate the influence of environmental variables and habitat on fish community biomass (R package vegan v 2.4.2). Variables included as vectors in the CCA were those that were statistically significant from the above forward stepwise regression procedure. Rare fish taxa $(\mathrm{Au}-$ lostomidae, Diodontidae, Fistularidae, Muraenidae, Pempheridae, Penguipedidae, Scorpaenidae and Sphyraenidae) were excluded from the analysis to reduce their influence on the explained variance (Legendre \& Legendre 1998). Two CCA were done, one that evaluated the site's fish composition with benthic cover and depth and the second with environmental variables and latitude. We produced scatterplots of the environmental and human influence variables versus latitude, biomass, and number of species.

\section{RESULTS}

\section{Community organization and fishable biomass}

Ten distinct clusters were identified by the SIMPRO method (Table 2, Table S1 in the Supplement). Somewhat less than $20 \%$ of the sites had very high biomass levels $>1400 \mathrm{~kg} \mathrm{ha}^{-1}$ (Table 3). A further $48 \%$ of sites had high biomass of $600-1400 \mathrm{~kg} \mathrm{ha}^{-1}$, while $31 \%$ had moderate and low biomass of $<600 \mathrm{~kg} \mathrm{ha}^{-1}$. The common and widespread cluster HSHB_Acanthuridae had both a moderate to high biomass $\sim 850 \mathrm{~kg} \mathrm{ha}^{-1}$ and even distribution of families (Table 3). The highest biomass clusters HSvHB_Acanthuridae and
HSvHB_Sphyraenidae (>2000 kg ha ${ }^{-1}$ ) had abundant grazing surgeonfish and parrotfish but also relatively high numbers of barracuda and groupers.

The biomass and number of species generally follow similar patterns and number of species increase and saturate asymptotically at 51 species per $500 \mathrm{~m}^{2}$ when biomass was $>1500 \mathrm{~kg} \mathrm{ha}^{-1}$ (Table 4, Figs. 2 $\& 3$ ). Cluster groupings were mostly driven by the fishable biomass and further distinguished by the fish's family composition (Table 3). When using raw site data, the number of species and the Simpson's diversity index were weakly positively correlated $\left(R^{2}=0.07, p=0.0001\right)$ but non-significant when the means of clusters were used. Because of some overlap in statistical significance between clusters, there were 3 or 4 distinct groups for number of species among the 10 clusters based on Dunn's tests of significance. The highest number of species was found in clusters HSHB_Others, HSHB_Lutjanidae, HSvHB_ Acanthuridae, and HSvHB_Sphyraenidae; however clusters HSHB_Acanthuridae and MSMB_Pomacentridae were not significantly different from the second group that included cluster MSMB_Scaridae with moderate number of species (Table 3). Clusters LSLB_Pomacentridae, MSMB_Acanthuridae, MSMB_ Pomacentridae, and MSMB_Scaridae were not significantly different from each other and formed a third group with low to moderate number of species while the forth group with the lowest number of species was composed of clusters MSMB_Acanthuridae, LSLB_Labridae, and LSLB_Pomacentridae. Simpson's proportional diversity ranged from 0.62 to 0.80 with clusters LSLB_Labridae, MSMB_Pomacentridae,

Table 2. Definitions, criteria and abbreviations of cluster categories identified in coral reef fish communities in the WNME. Detailed descriptions of the data for each cluster are summarized in Table S1 in the Supplement

\begin{tabular}{|c|c|c|c|c|c|}
\hline $\begin{array}{l}\text { Cluster species } \\
\text { abbreviation }\end{array}$ & $\begin{array}{l}\text { Definition of species } \\
\text { clusters }\end{array}$ & $\begin{array}{l}\text { Cluster biomass } \\
\text { abbreviation }\end{array}$ & $\begin{array}{l}\text { Cluster biomass } \\
\text { definition }\end{array}$ & $\begin{array}{l}\text { Cluster } \\
\text { number }\end{array}$ & $\begin{array}{l}\text { Cluster name } \\
\text { abbreviation }\end{array}$ \\
\hline LS & $\begin{array}{l}\text { Low species } \\
\left(0-30 \text { species per } 500 \mathrm{~m}^{2}\right)\end{array}$ & LB & $\begin{array}{l}\text { Low biomass } \\
\left(<300 \mathrm{~kg} \mathrm{ha}^{-1}\right)\end{array}$ & 1 & LSLB_Labridae \\
\hline MS & $\begin{array}{l}\text { Moderate species } \\
\left(30-40 \text { species per } 500 \mathrm{~m}^{2}\right)\end{array}$ & $\mathrm{MB}$ & $\begin{array}{l}\text { Moderate biomass } \\
\left(300-600 \mathrm{~kg} \mathrm{ha}^{-1}\right)\end{array}$ & 2 & LSLB_Pomacentridae \\
\hline \multirow[t]{8}{*}{ HS } & $\begin{array}{l}\text { High species } \\
\left(>40 \text { species per } 500 \mathrm{~m}^{2} \text { ) }\right.\end{array}$ & HB & $\begin{array}{l}\text { High biomass } \\
\left(600-1400 \mathrm{~kg} \mathrm{ha}^{-1}\right)\end{array}$ & 3 & MSMB_Acanthuridae \\
\hline & & vHB & $\begin{array}{l}\text { Very high biomass } \\
\left(>1400 \mathrm{~kg} \mathrm{ha}^{-1}\right)\end{array}$ & 4 & MSMB_Pomacentridae \\
\hline & & _fish family & $\begin{array}{l}\text { Dominant fish taxa or } \\
\text { category in cluster }\end{array}$ & 5 & MSMB_Scaridae \\
\hline & & & & 6 & HSHB_Acanthuridae \\
\hline & & & & 7 & HSHB_Others \\
\hline & & & & 8 & HSHB_Lutjanidae \\
\hline & & & & 9 & HSvHB_Acanthuridae \\
\hline & & & & 10 & HSvHB_Sphyraenidae \\
\hline
\end{tabular}




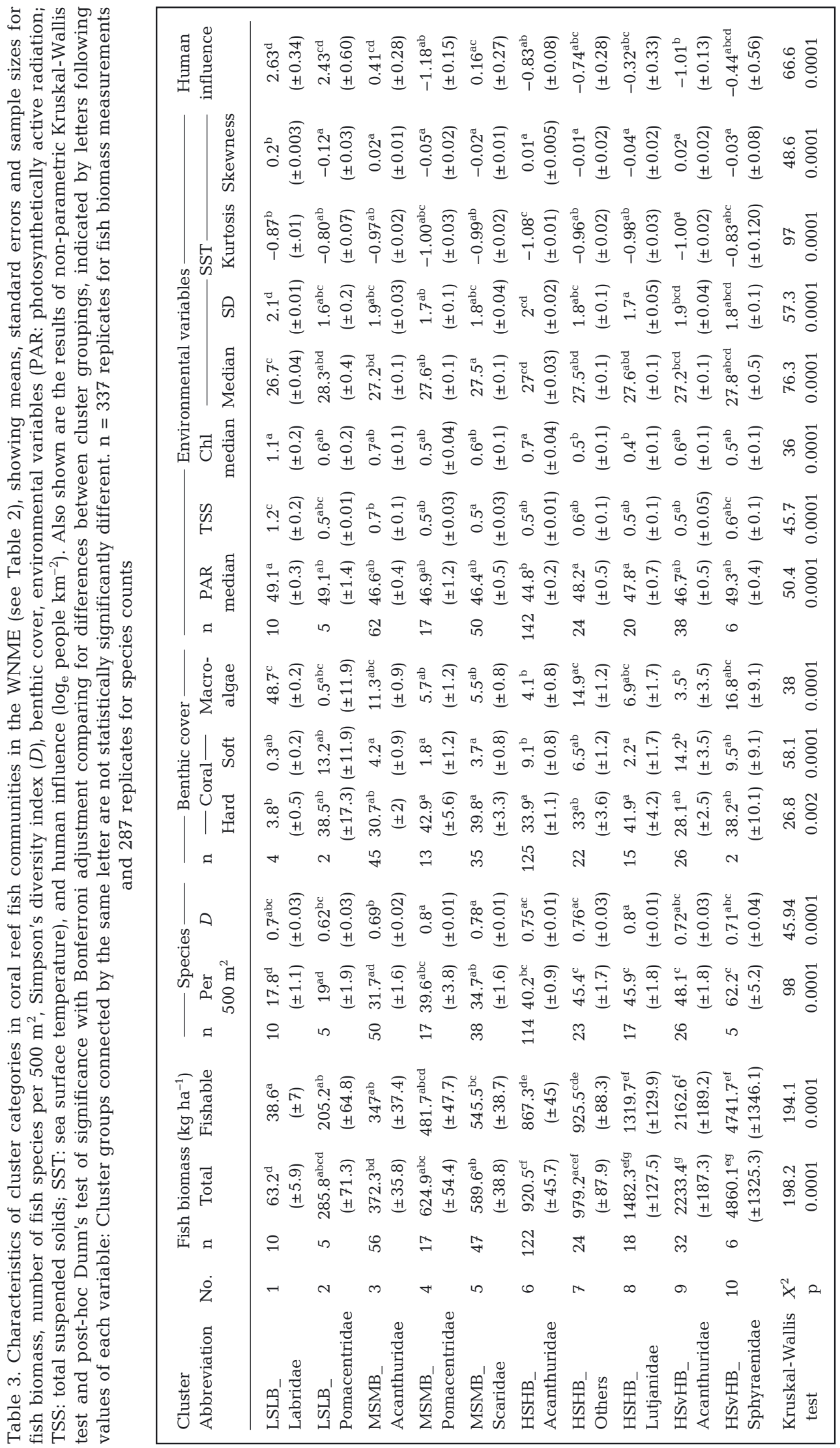


Table 4. Statistical results of the test of fits for relationship between biomass and number of fish species for 4 likely equation models. AIC: Akaike information criterion

\begin{tabular}{|c|c|c|c|c|c|c|c|c|c|}
\hline \multirow[t]{2}{*}{ Model } & \multirow[t]{2}{*}{ Term } & \multirow[t]{2}{*}{ Estimate } & \multicolumn{2}{|c|}{ Asymptotic b } & \multirow[t]{2}{*}{$t$} & \multirow{2}{*}{$\mathrm{p}>|t|$} & \multirow[t]{2}{*}{ AIC } & \multirow[t]{2}{*}{$\mathrm{p}$} & \multirow[t]{2}{*}{$\mathrm{R}^{2}$} \\
\hline & & & $90 \%$ & $95 \%$ & & & & & \\
\hline \multirow[t]{3}{*}{ Asymptote } & $\mathrm{k}$ & $51.52 \pm 2.05$ & \multirow[t]{3}{*}{1508.90} & \multirow[t]{3}{*}{1963.13} & 25.18 & 0.0001 & \multirow[t]{3}{*}{2254.4} & \multirow[t]{3}{*}{0.0001} & \multirow[t]{3}{*}{0.40} \\
\hline & Bo & $19.11 \pm 2.08$ & & & 9.2 & 0.0001 & & & \\
\hline & $\mathrm{r}$ & $0.002 \pm 0.0002$ & & & 5.72 & 0.0001 & & & \\
\hline \multirow{3}{*}{ Logistic } & $\mathrm{k}$ & $49.80 \pm 1.68$ & \multirow[t]{8}{*}{1248.26} & \multirow[t]{6}{*}{1541.43} & 29.6 & 0.0001 & \multirow[t]{3}{*}{2260.6} & \multirow[t]{3}{*}{0.0001} & \multirow[t]{3}{*}{0.39} \\
\hline & Bo & $21.66 \pm 1.66$ & & & 13.03 & 0.0001 & & & \\
\hline & $\mathrm{r}$ & $0.002 \pm 0.0004$ & & & 6.45 & 0.002 & & & \\
\hline \multirow[t]{3}{*}{ Ricker } & Bo & $25.88 \pm 1.33$ & & & 19.5 & 0.0001 & \multirow[t]{3}{*}{2276.7} & \multirow{3}{*}{0.0001} & \multirow[t]{3}{*}{0.35} \\
\hline & $\mathrm{a}$ & $0.02 \pm 0.003$ & & & 8.36 & 0.0001 & & & \\
\hline & $\mathrm{b}$ & $0.0002 \pm 0.00003$ & & & 4.69 & 0.0001 & & & \\
\hline \multirow[t]{2}{*}{ Linear } & Intercept & $33.04 \pm 0.84$ & & & 39.56 & 0.0001 & \multirow[t]{2}{*}{2318.7} & \multirow[t]{2}{*}{0.0001} & \multirow[t]{2}{*}{0.25} \\
\hline & Fishable biomass $\left(\mathrm{kg} \mathrm{ha}^{-1}\right)$ & $0.01 \pm 0.001$ & & & 10.11 & 0.0001 & & & \\
\hline
\end{tabular}
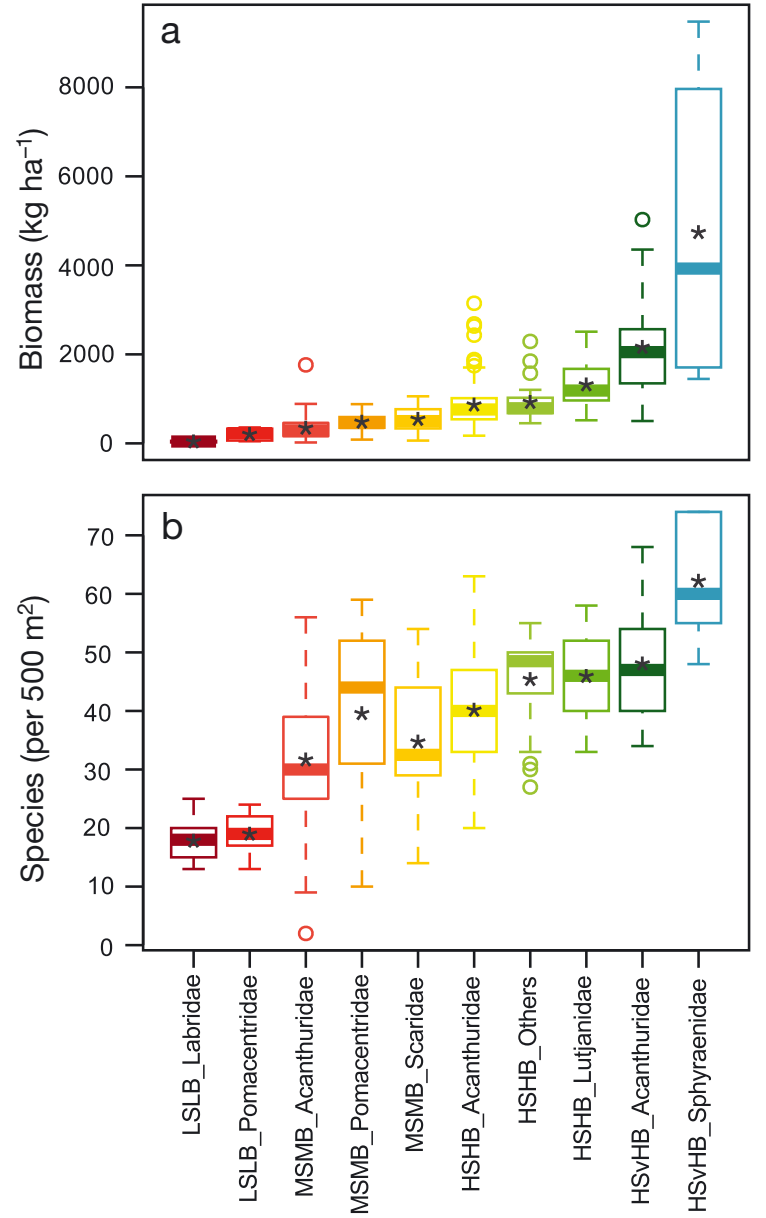

Fig. 2. (a) Biomass and (b) number of local species in 9 families per $500 \mathrm{~m}^{2}$ for each of 10 cluster groups identified in coral reef fish communities in the WNME (Table 2). Cluster groups are shown left to right from lowest (red) to highest biomass (blue). Black asterisks: mean values for each category; thick bars: medians; boxes: interquartile range (IQR); whiskers: $\min . / \max$. values $\leq 1.5 \times \mathrm{IQR}_{\text {; }}$ open circles: suspected outliers $>1.5 \times$ IQR

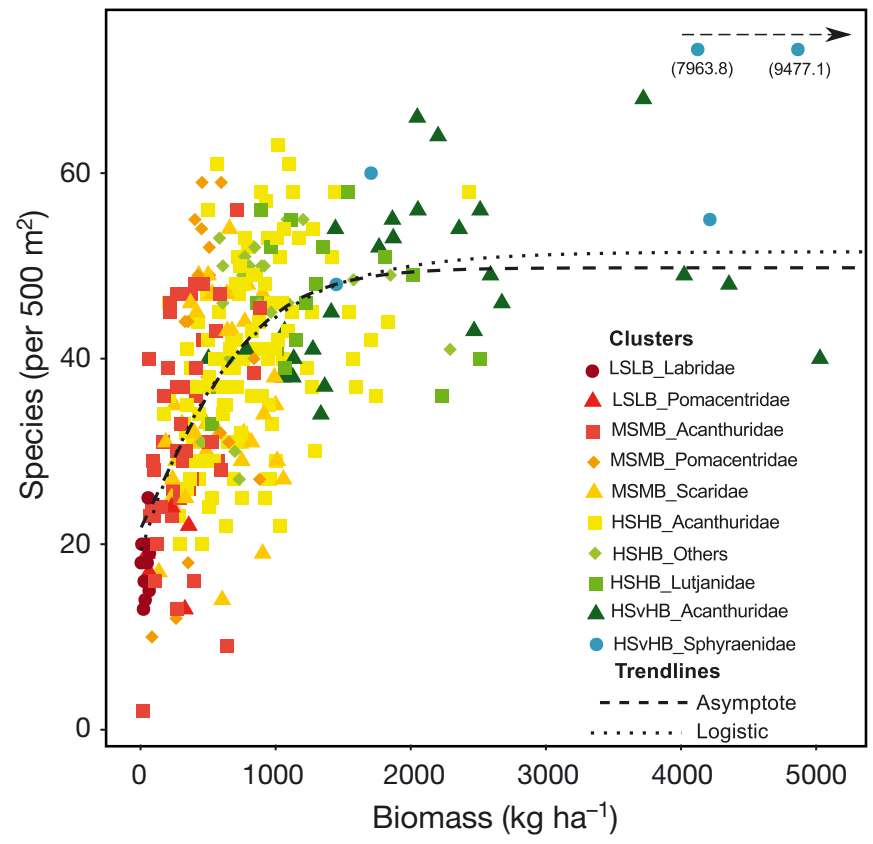

Fig. 3. Relationship between fishable biomass and number of species in 9 families per $500 \mathrm{~m}^{2}$ at study sites in the WNME. Study sites are differentiated by the association with 10 reef fish cluster groups (Table 2), listed in order from lowest (red) to highest biomass (blue)

MSMB_Scaridae, HSHB_Acanthuridae, HSHB Others, HSHB_Lutjanidae, HSvHB_Acanthuridae, and HSvHB_Sphyraenidae having high diversity while clusters MSMB_Pomacentridae and LSLB_ Pomacentridae had low diversity.

Spatial structure differed from random, but fish family cluster groups were broadly distributed throughout the region (Figs. 1 \& 4). For example, TSS, chloro- 

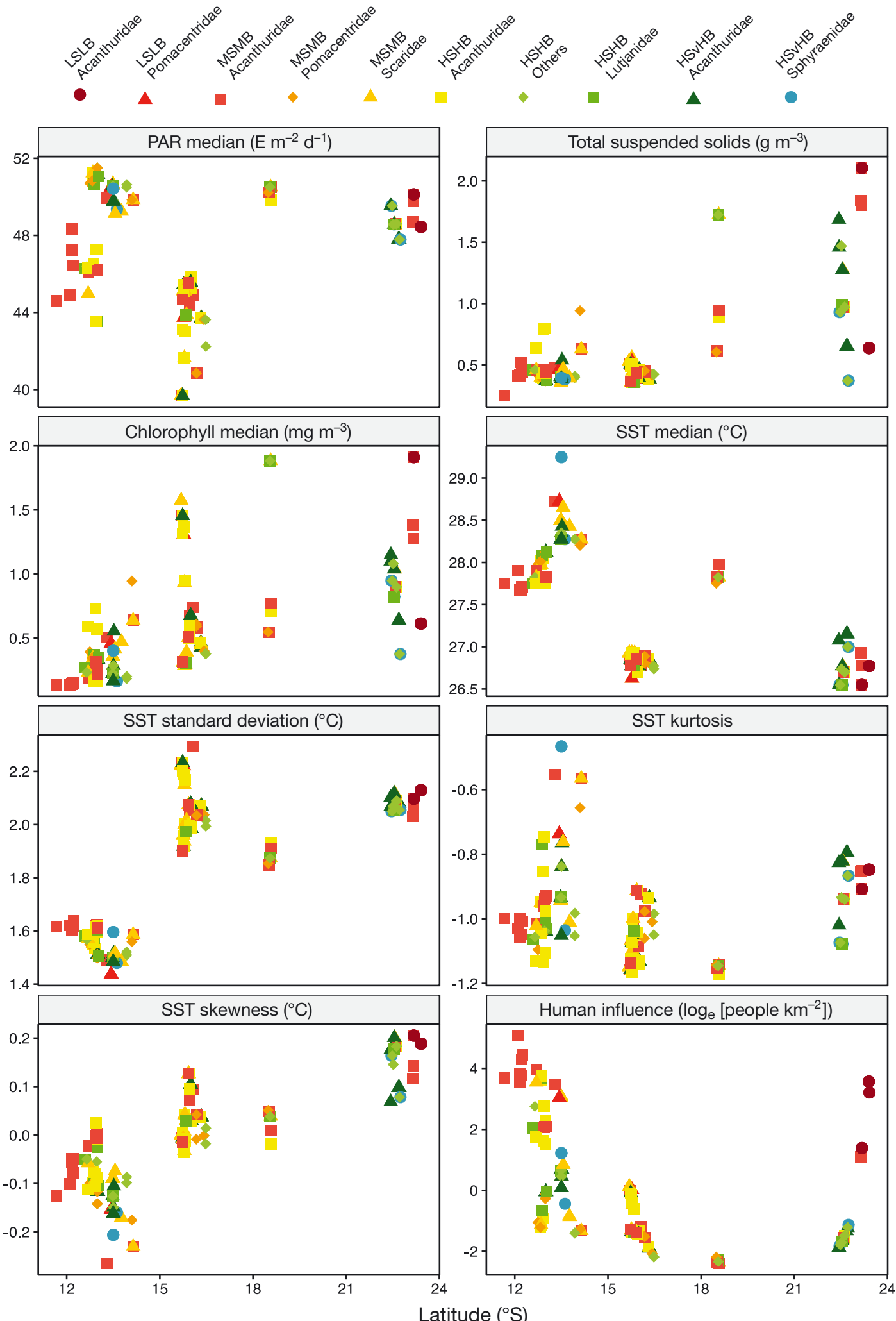

Fig. 4. Scatterplots of the 7 environmental and human influence variables at study sites in the WMNE, plotted against their latitude. Study sites are differentiated by the association with 10 reef fish cluster groups (Table 2), listed in order from lowest (red) to highest biomass (blue). Many replicate points overlay each other and cannot be seen because they share the same environmental conditions 
phyll concentrations, temperature variance and SST skewness increased towards higher latitudes whereas median SST and PAR showed the opposite patterns. Human influence showed a unimodal pattern with highest influences in the northern and southern region. There were a few latitudinal patterns in the distribution of the fish communities; for example, the very lowest biomass cluster LSLB_Labridae occurred in the southern Toliara reef lagoons. Moderate biomass clusters were more broadly distributed while low biomass sites were frequently located near population centers, such as Nosy Be and the Comoros Islands. However, Mayotte, in contrast to Grande Comoros and Anjuan, had high biomass in many of the offshore reefs that were near population centers. High biomass was also found in some offshore sites, such as the Barren Islands, the Anjoviny and Mitsio Islands. Masoala and Antonginal Bay on the east coast had had moderate biomass levels. The nearshore reefs from Androvona to Tsiandamba also had high biomass. Overall, despite some spatial structure in the biomass, numbers of species, and community axes, the spatial autocorrelations or clustering strengths were weak (Table 5). For examples, Moran's I for biomass was 0.006 and 0.025 at transect and site levels.

Many sites in the low to moderate biomass regions were dominated by low value non-target fisheries families (i.e. Fistularidae, Aulostomidae, Penguipedidae, Muraenidae, Diodontidae, Scorpaenidae, and Pomacentridae). The higher value target fisheries taxa (i.e. Lethrinidae, Haemulidae, Serranidae, Holocentridae, Sphyraenidae, Labridae, Scaridae, Carangidae, Acanthuridae, and Mullidae) were more commonly found in deeper waters and in some remote areas. Analysis showed that $17 \%$ of the replicates were in clusters with high biomass (>1200 $\mathrm{kg} \mathrm{ha}^{-1}$ ) high number of species ( $>45$ species), namely clusters HSHB_Lutjanidae, HSvHB_Acanthuridae, and HSvHB_Sphyraenidae. $43 \%$ of the sites had moderate biomass ( 900 kg ha $\left.{ }^{-1}\right)$ and high numbers of species in cluster HSHB_Others and moderate numbers in cluster HSHB_Acanthuridae. HSHB_Acanthuridae was the most common single cluster containing $36 \%$ of the replicate sites and typified by having moderate and even abundance among most families. In total, $40 \%$ of the sites were classified into the 5 clusters with biomass $<600 \mathrm{~kg} \mathrm{ha}^{-1}$, with clusters LSLB_ Pomacentridae, MSMB_Acanthuridae, MSMB_Poma- centridae, and MSMB_Scaridae having low to moderate biomass (285 to $625 \mathrm{~kg} \mathrm{ha}^{-1}$ ) and cluster LSLB_Labridae having the lowest biomass (60 kg $\mathrm{ha}^{-1}$ ). Cluster MSMB_Acanthuridae was unique in having moderate levels of surgeonfish and some parrotfish but low biomass of the other taxa. These low biomass sites were all associated with our high human influence metric.

\section{Associations among environmental and reef community variables}

Benthic cover. Forward stepwise regressions evaluating depth, benthic cover, human influences, and environmental variable associations found weak whole model fits for these variables and benthic cover. Hard coral cover was positively associated with median SST and negatively with human influence, SST kurtosis (centralized distributions), SST right skewness, and median PAR (Table 6). Soft coral was, however, positively associated with median PAR, depth, SST standard deviation and negatively with TSS. Erect macroalgae cover was positively associated with human influence, TSS, SST standard deviations, median PAR, and depth and negatively with chlorophyll concentrations.

Fish biomass and family composition associations. The first 2 multivariate axes of the family composition were evaluated for autocorrelations in space and associations with environmental, human influence, and benthic variables prior to establishing vectors for the CCA plots (Tables 5 \& 7). Moran's index of spatial autocorrelations for both community structure axes indicated weak spatial clustering that was only significant for Axis 2, associated with slightly higher Pomacentridae numbers and a few other families in 
Table 6. Associations of (a) hard coral, (b) soft coral, and (c) erect macroalgae by forward stepwise regression using Akaike information criterion (AIC) stopping rule criteria (see 'Materials and methods') with depth, human influence and 7 selected satellite-derived environmental variables. Parameters are listed from strongest to weakest association for each benthic metric. SST: sea surface temperature; PAR: photosynthetically active radiation; TSS: total suspended solids; VIF: variance inflation factor; ns: not significant $(\mathrm{p}>0.1)$

\begin{tabular}{|c|c|c|c|c|c|c|c|}
\hline Parameter & Estimate & $t$ & $F$-ratio & $\mathrm{p}>F$ & VIF & $\mathrm{R}^{2}$ & Whole-model $\mathrm{p}$ \\
\hline \multicolumn{8}{|l|}{ (a) Hard coral (\%) } \\
\hline Intercept & $-245.6 \pm 98.6$ & -2.5 & 0 & 0.01 & & 0.09 & 0.0001 \\
\hline SST median $\left({ }^{\circ} \mathrm{C}\right)$ & $11.1 \pm 4.0$ & 2.8 & 7.9 & 0.01 & 7.01 & & \\
\hline Human influence & $-1.7 \pm 0.7$ & -2.4 & 6.1 & 0.02 & 1.41 & & \\
\hline SST kurtosis & $-18.0 \pm 8.7$ & -2.1 & 4.1 & 0.04 & 1.61 & & \\
\hline PAR median $\left(\mathrm{E} \mathrm{m}^{-2} \mathrm{~d}^{-1}\right)$ & $-0.9 \pm 0.5$ & -1.9 & 4.0 & 0.06 & 2.77 & & \\
\hline SST skewness $\left({ }^{\circ} \mathrm{C}\right)$ & $-6.4 \pm 19.1$ & -0.3 & 0.1 & ns & 3.55 & & \\
\hline SST standard deviation $\left({ }^{\circ} \mathrm{C}\right)$ & & & 0.3 & ns & & & \\
\hline Depth $(\mathrm{m})$ & & & 0.2 & ns & & & \\
\hline TSS median $\left(\mathrm{g} \mathrm{m}^{-3}\right)$ & & & 0.1 & ns & & & \\
\hline Chlorophyll median $\left(\mathrm{mg} \mathrm{m}^{-3}\right)$ & & & 0 & ns & & & \\
\hline \multicolumn{8}{|l|}{ (b) Soft coral (\%) } \\
\hline Intercept & $-68.5 \pm 22.1$ & -3.1 & 0 & 0.002 & & 0.11 & 0.0001 \\
\hline PAR median $\left(\mathrm{E} \mathrm{m}^{-2} \mathrm{~d}^{-1}\right)$ & $1.3 \pm 0.3$ & 3.9 & 15.5 & 0.0001 & 3.86 & & \\
\hline TSS median $\left(\mathrm{g} \mathrm{m}^{-3}\right)$ & $-4.8 \pm 2.3$ & -2.1 & 4.3 & 0.04 & 1.75 & & \\
\hline Depth (m) & $0.3 \pm 0.1$ & 1.9 & 3.7 & 0.05 & 1.08 & & \\
\hline SST standard deviation $\left({ }^{\circ} \mathrm{C}\right)$ & $8.5 \pm 4.6$ & 1.9 & 3.4 & 0.07 & 4.23 & & \\
\hline Human influence & $-0.6 \pm 0.4$ & -1.3 & 1.8 & ns & 1.49 & & \\
\hline Chlorophyll median $\left(\mathrm{mg} \mathrm{m}^{-3}\right)$ & & & 1.5 & ns & & & \\
\hline SST skewness $\left({ }^{\circ} \mathrm{C}\right)$ & & & 1.3 & ns & & & \\
\hline SST median $\left({ }^{\circ} \mathrm{C}\right)$ & & & 0.1 & ns & & & \\
\hline SST kurtosis & & & 0 & ns & & & \\
\hline \multicolumn{8}{|l|}{ (c) Erect macroalgae (\%) } \\
\hline Intercept & $-132.3 \pm 22$ & -6.0 & 0 & 0.0001 & & 0.45 & 0.0001 \\
\hline Human influence & $2.7 \pm 0.4$ & 6.1 & 37.7 & 0.0001 & 1.54 & & \\
\hline TSS median $\left(\mathrm{g} \mathrm{m}^{-3}\right)$ & $17.5 \pm 2.9$ & 6.1 & 37.0 & 0.0001 & 2.69 & & \\
\hline PAR median $\left(\mathrm{E} \mathrm{m}^{-2} \mathrm{~d}^{-1}\right)$ & $1.9 \pm 0.3$ & 5.8 & 33.0 & 0.0001 & 4.17 & & \\
\hline SST standard deviation $\left({ }^{\circ} \mathrm{C}\right)$ & $23.2 \pm 4.8$ & 4.8 & 23.1 & 0.0001 & 4.70 & & \\
\hline Chlorophyll median $\left(\mathrm{mg} \mathrm{m}^{-3}\right)$ & $-5.7 \pm 2.0$ & -2.8 & 8.1 & 0.005 & 3.06 & & \\
\hline Depth $(\mathrm{m})$ & $0.3 \pm 0.1$ & 2.0 & 3.8 & 0.05 & 1.09 & & \\
\hline SST kurtosis) & & & 1.9 & ns & & & \\
\hline SST median $\left({ }^{\circ} \mathrm{C}\right)$ & & & 0.1 & ns & & & \\
\hline SST skewness $\left({ }^{\circ} \mathrm{C}\right)$ & & & 0.1 & ns & & & \\
\hline
\end{tabular}

the north. Among the environmental variables, only latitude and SST median were retained for the CCA. Consequently, CCA of the family composition indicated overall weak patterns with $5.7 \%$ and $3.0 \%$ of the variance explained by Axes 1 and 2 (Fig. 5a). Axis 1 separates sites by latitude with more typical coral reef family abundance, such as Pomacentridae, Siganidae, Pomacanthidae, and Balistidae, higher in lower northern latitudes. More generalist families, such as Lethrinidae, Mullidae, Haemulidae, and Holocentridae, were higher in southern latitudes.

Fish biomass associations with depth, benthic cover, and human influence by forward stepwise regressions also found weak whole model fits (Table 7 , Fig. S2). Depth was strongest and soft coral significantly positively, while erect algae was negatively associated with biomass, and there was no relation- ship with our human influence metric. Consequently, CCA of the family composition with retained depth and benthic variables was also weak with 4.9 and $3.7 \%$ of the variance explained by the Axis 1 and 2, respectively (Fig. 5b). The primary division was between hard coral and soft coral and depth and erect algae cover whereas Axis 2 separated erect macroalgae and soft coral. Most sites were associated with the shallow hard coral axis and dominated by typical coral reef fish families, such as Pomacentridae, Chaetodontidae, Labridae, Scaridae, Pomacanthidae, and Acanthuridae. Larger bodied and more generalist species were associated with the deeper soft coral axis including the Lethridinae, Serranidae, Haemulidae, Mullidae, and Balistidae. Erect algae cover was associated with Lutjanidae and the 'others' group. Siganidae were, perhaps unexpectedly, rela- 
Table 7. (a) Associations between fish biomass and benthic and environmental variables found by forward stepwise regression. Fish family composition CCA axes evaluated by canonical correspondence analysis (CCA) for associations with (b) benthic and (c) environmental variables. Parameters are listed from strongest to weakest association for each metric. Significant variables were retained by forward AIC stepwise and Monte-Carlo permutation tests $(p<0.05)$. For abbreviations see Table 6 legend

\begin{tabular}{|c|c|c|c|c|c|c|c|}
\hline Parameter & Estimate & $t$ & F-ratio & $\mathrm{p}>F$ & VIF & $\mathrm{R}^{2}$ & Whole-model p \\
\hline \multicolumn{8}{|c|}{ (a) Fishable biomass $\left(\mathrm{kg} \mathrm{ha}^{-1}\right)$ and benthic and environmental variables } \\
\hline Intercept & $628.5 \pm 109$ & 5.73 & 0 & 0.0001 & & 0.06 & 0.001 \\
\hline Depth (m) & $26.8 \pm 12.1$ & 2.22 & 4.9 & 0.03 & 1.01 & & \\
\hline Soft coral $(\%)$ & $10.3 \pm 4.7$ & 2.2 & 4.9 & 0.03 & 1.02 & & \\
\hline Macroalgae (\%) & $-7.9 \pm 3.8$ & -2.07 & 4.3 & 0.04 & 1.01 & & \\
\hline TSS median $\left(\mathrm{g} \mathrm{m}^{-}\right.$ & & & 1.5 & ns & & & \\
\hline SST skewness $\left({ }^{\circ} \mathrm{C}\right.$ & & & 1.0 & ns & & & \\
\hline Chlorophyll media & $\left.\mathrm{m}^{-3}\right)$ & & 0.7 & ns & & & \\
\hline PAR median $\left(\mathrm{E} \mathrm{m}^{-}\right.$ & & & 0.3 & ns & & & \\
\hline SST kurtosis & & & 0.1 & ns & & & \\
\hline Human influence & & & 0.1 & ns & & & \\
\hline SST standard devi & $\left({ }^{\circ} \mathrm{C}\right)$ & & 0.1 & ns & & & \\
\hline SST median $\left({ }^{\circ} \mathrm{C}\right)$ & & & 0.0 & ns & & & \\
\hline Parameter & CCA Axis 1 score & CCA Axis 2 score & F-ratio & $\mathrm{p}>F$ & VIF & $\mathrm{R}^{2}$ & Whole-model p \\
\hline \multicolumn{8}{|c|}{ (b) Fish community structure and benthic variables } \\
\hline Depth (m) & -0.74 & -0.007 & 5.09 & 0.01 & 1.12 & 0.11 & 0.001 \\
\hline Macroalgae (\%) & -0.46 & 0.62 & 4.34 & 0.02 & 1.12 & & \\
\hline Soft coral (\%) & -0.64 & -0.37 & 4.34 & 0.04 & 1.09 & & \\
\hline Hard coral $(\%)$ & 0.33 & 0.64 & 3.66 & 0.05 & 1.14 & & \\
\hline \multicolumn{8}{|c|}{ (c) Fish community structure and environmental variables } \\
\hline Latitude & -0.94 & -0.31 & 9.65 & 0.002 & 1.86 & 0.09 & 0.001 \\
\hline SST median $\left({ }^{\circ} \mathrm{C}\right)$ & 0.42 & 0.91 & 5.71 & 0.20 & 1.86 & & \\
\hline PAR median (E m- & & & 2.62 & ns & & & \\
\hline Longitude & & & 2.35 & ns & & & \\
\hline SST standard devi & $\left({ }^{\circ} \mathrm{C}\right)$ & & 1.46 & ns & & & \\
\hline SST kurtosis & & & 1.82 & ns & & & \\
\hline TSS median $\left(\mathrm{g} \mathrm{m}^{-}\right.$ & & & 1.29 & ns & & & \\
\hline SST skewness $\left({ }^{\circ} \mathrm{C}\right)$ & & & 1.27 & ns & & & \\
\hline Chlorophyll media & $\left.\mathrm{m}^{-3}\right)$ & & 1.07 & ns & & & \\
\hline Human influence & & & 1.22 & ns & & & \\
\hline
\end{tabular}

tively more common in the shallow coral dominated than erect macroalgae dominated sites.

Number of species. The number of fish species was evaluated for spatial association patterns with the raw site average numbers and also using residual number of species from the biomass-species relationships (Tables 5 \& 8, Fig. S3). The number of fish species among sites was significantly different from no or random spatial patterns but weakly aggregated in space (Table 5). When the fishable biomass variable was included in the predictive models the overall model fits increased $\left(\mathrm{R}^{2}=0.38\right.$ and 0.41 , for BIC and $\mathrm{AIC}$, respectively) compared to when using the residual number of species from biomass $\left(\mathrm{R}^{2}=0.25\right.$ and 0.28 , respectively) (Table 8 ). For the number of species based on site averages, the liberal AIC stopping rule criteria found 5 significant variables positively associated with number of species: fishable biomass was the strongest, followed by PAR, percent hard coral, median SST, and depth was the weakest significant variable. The other 8 variables, including human influence, were not significant. The conservative BIC criteria found 3 variables positively associated with number of species, namely biomass, PAR, and the percentage cover of hard coral.

Using the residuals of number of species from the biomass-number of species relationships and the AIC stopping rules found positive relationships for PAR, median SST, and TSS but only the first 2 variables were strongly significant. Percentage soft coral was strongly negatively associated with the residuals of number of species. When the restrictive BIC stopping rules were used, only PAR was significantly positive and soft coral significantly negatively associated with number of species. Testing for nonlinear found little improvement from linear relationships for the 

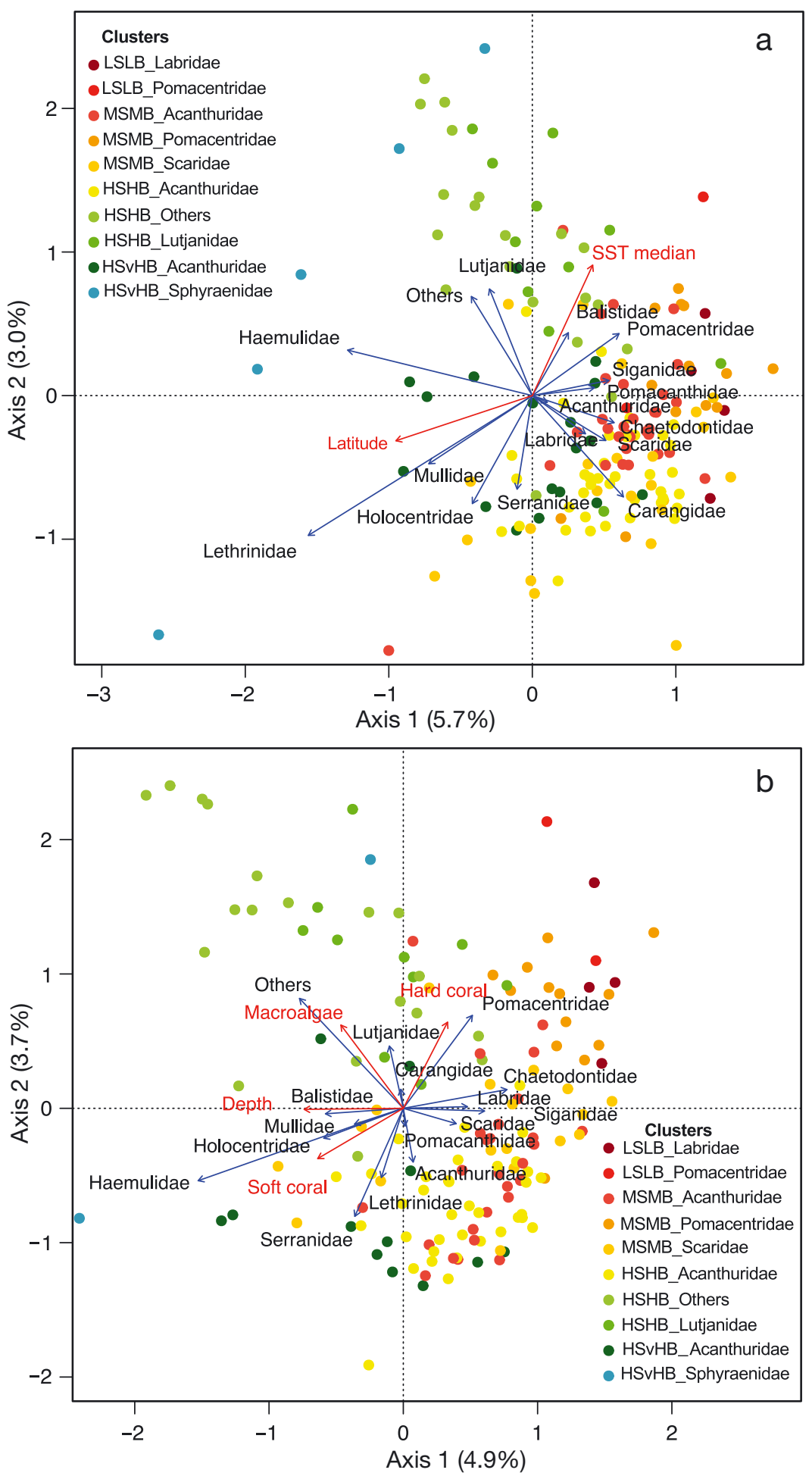

Fig. 5. Multivariate ordination based on canonical correspondence analysis (CCA) of study sites in the WNME and their associations with (a) the significant environmental variables and latitude and (b) benthic cover and depth variables. Study sites are differentiated by the association with 10 reef fish cluster groups (Table 2), listed in order from lowest (red) to highest biomass (blue). Vectors included were chosen by forward stepwise regression analysis. The percent variance explained here is based on the composite influence of the chosen variables (red vectors) average number of species but some improvements in the fit when using the residual number of species from biomass (Table 9, Fig. S4). Improved model fit to second order polynomial for the residuals was found with TSS, chlorophyll, SST median, standard deviation and SST skewness but improvements were small (maximum increase in $\mathrm{R}^{2}$ of $3 \%$ ).

\section{DISCUSSION}

\section{Fish communities and their distributions}

This large-scale evaluation of WNME reefs indicates that there were 10 distinct communities when fish were evaluated at the family level. Communities could be distinguished by gradient of biomass, number of species, and the dominant families. However, these families were not strongly structured in space and therefore would appear organized at very local temporal and spatial scales that may represent behavioral patterns rather than strong local habitat, environment, and human fishing influences. In general, there were few regions that had consistent or strong associations with family composition, high biomass, or number of species. Given the large amount of unexplained variation, we cannot conclude that habitat and environmental factors were strong forces influencing fish communities at this taxonomic scale.

Community state at the family level largely reflects the gross functional roles of fish and this is a good taxonomic scale to examine the distribution of functional roles. At this family level, there was little indication of strong spatial clustering and unique locations despite considerable gradients in environmental and human influence. Some sites exhibited abundance and family compositions that might indicate latitude, habitat, and human influences but the responses 
Table 8. Associations between numbers of coral reef fish species and other parameters evaluated by forward stepwise regression results using (a) AIC and (b) Bayesian information criterion (BIC) stopping rule criteria (see 'Materials and methods') based on raw species data and using (c) AIC and (d) BIC stopping rule criteria based on residuals from the biomass-number of species relationship. Parameters are listed from strongest to weakest association for each evaluated biomass metric. $\mathrm{p}=(\mathrm{a}, \mathrm{b}, \mathrm{d}) \mathrm{p}>F_{1}(\mathrm{c}) \mathrm{p}>|t|$. For abbreviations see Table 6 legend

\begin{tabular}{|c|c|c|c|c|c|c|c|}
\hline Parameter & Estimate & $t$ & $F$ & $\mathrm{p}>F$ & VIF & $\mathrm{R}^{2}$ & Whole-model p \\
\hline \multicolumn{8}{|c|}{ (a) AIC criteria including fishable biomass } \\
\hline Intercept & $-114.9 \pm 32.1$ & -3.6 & 0 & 0.0004 & & 0.41 & 0.0001 \\
\hline Fishable biomass $\left(\mathrm{kg} \mathrm{ha}^{-1}\right)$ & $0.008 \pm 0.001$ & 8.1 & 65.6 & 0.0001 & 1.04 & & \\
\hline PAR median $\left(\mathrm{E} \mathrm{m}^{-2} \mathrm{~d}^{-1}\right)$ & $1.0 \pm 0.2$ & 4.0 & 16.4 & 0.0001 & 1.74 & & \\
\hline Hard coral (\%) & $0.1 \pm 0.04$ & 2.9 & 8.2 & 0.005 & 1.10 & & \\
\hline $\mathrm{SST}$ median $\left({ }^{\circ} \mathrm{C}\right)$ & $3.5 \pm 1.4$ & 2.5 & 6.2 & 0.01 & 1.95 & & \\
\hline Depth (m) & $0.4 \pm 0.2$ & 2.3 & 5.3 & 0.02 & 1.12 & & \\
\hline Soft coral (\%) & & & 1.5 & ns & & & \\
\hline TSS median $\left(\mathrm{g} \mathrm{m}^{-3}\right)$ & & & 1.4 & ns & & & \\
\hline Chlorophyll median $\left(\mathrm{mg} \mathrm{m}^{-3}\right)$ & & & 1.3 & ns & & & \\
\hline SST kurtosis & & & 1.1 & ns & & & \\
\hline SST skewness $\left({ }^{\circ} \mathrm{C}\right)$ & & & 0.5 & ns & & & \\
\hline SST standard deviation $\left({ }^{\circ} \mathrm{C}\right)$ & & & 0.2 & ns & & & \\
\hline Human influence & & & 0 & ns & & & \\
\hline Macroalgae (\%) & & & 0 & ns & & & \\
\hline \multicolumn{8}{|c|}{ (b) BIC criteria including fishable biomass } \\
\hline Intercept & $-34.5 \pm 8.6$ & -4.0 & 0.0 & 0.0001 & & 0.38 & 0.0001 \\
\hline Fishable biomass $\left(\mathrm{kg} \mathrm{ha}^{-1}\right)$ & $0.008 \pm 0.001$ & 8.6 & 73.2 & 0.0001 & 1.00 & & \\
\hline PAR median $\left(\mathrm{E} \mathrm{m}^{-2} \mathrm{~d}^{-1}\right)$ & $1.3 \pm 0.2$ & 7.3 & 52.6 & 0.0001 & 1.00 & & \\
\hline Hard coral $(\%)$ & $0.1 \pm 0.04$ & 3.7 & 13.9 & 0.0002 & 1.00 & & \\
\hline SST median $\left({ }^{\circ} \mathrm{C}\right)$ & & & 3.7 & 0.05 & & & \\
\hline Depth $(\mathrm{m})$ & & & 2.9 & 0.09 & & & \\
\hline SST standard deviation $\left({ }^{\circ} \mathrm{C}\right)$ & & & 1.7 & ns & & & \\
\hline SST skewness $\left({ }^{\circ} \mathrm{C}\right)$ & & & 1.6 & ns & & & \\
\hline Soft coral (\%) & & & 1.6 & ns & & & \\
\hline Human influence & & & 0.8 & ns & & & \\
\hline SST kurtosis & & & 0.6 & ns & & & \\
\hline Chlorophyll median $\left(\mathrm{mg} \mathrm{m}^{-3}\right)$ & & & 0.4 & ns & & & \\
\hline Macroalgae (\%) & & & 0.1 & ns & & & \\
\hline TSS median $\left(\mathrm{g} \mathrm{m}^{-3}\right)$ & & & 0.0 & ns & & & \\
\hline \multicolumn{8}{|c|}{ (c) Residuals of fishable biomass (AIC based) } \\
\hline Intercept & $-143.9 \pm 28.9$ & -5.0 & 0.0 & 0.0001 & & 0.28 & 0.0001 \\
\hline PAR median $\left(\mathrm{E} \mathrm{m}^{-2} \mathrm{~d}^{-1}\right)$ & $0.9 \pm 0.2$ & 3.8 & 14.5 & 0.0002 & 2.32 & & \\
\hline $\mathrm{SST}$ median $\left({ }^{\circ} \mathrm{C}\right)$ & $3.6 \pm 1.3$ & 2.8 & 7.8 & 0.006 & 2.10 & & \\
\hline Soft coral $(\%)$ & $-0.2 \pm 0.1$ & -2.7 & 7.0 & 0.009 & 1.12 & & \\
\hline TSS median $\left(\mathrm{g} \mathrm{m}^{-3}\right)$ & $3.6 \pm 1.9$ & 1.9 & 3.5 & 0.06 & 1.28 & & \\
\hline Depth (m) & $0.2 \pm 0.1$ & 1.5 & 2.3 & ns & 1.10 & & \\
\hline Hard coral (\%) & & & 1.9 & ns & & & \\
\hline SST kurtosis & & & 0.7 & $\mathrm{~ns}$ & & & \\
\hline Human influence & & & 0.3 & ns & & & \\
\hline Chlorophyll median $\left(\mathrm{mg} \mathrm{m}^{-3}\right)$ & & & 0.1 & ns & & & \\
\hline Macroalgae (\%) & & & 0.1 & ns & & & \\
\hline SST skewness $\left({ }^{\circ} \mathrm{C}\right)$ & & & 0.0 & ns & & & \\
\hline SST standard deviation $\left({ }^{\circ} \mathrm{C}\right)$ & & & 0.0 & ns & & & \\
\hline \multicolumn{8}{|c|}{ (d) Residuals of fishable biomass (BIC based) } \\
\hline Intercept & $-66.1 \pm 7.6$ & -8.7 & 0.0 & 0.0001 & & 0.25 & 0.0001 \\
\hline PAR median $\left(\mathrm{E} \mathrm{m}^{-2} \mathrm{~d}^{-1}\right)$ & $1.5 \pm 0.2$ & 8.7 & 74.1 & 0.0001 & 1.10 & & \\
\hline Soft coral $(\%)$ & $-0.2 \pm 0.1$ & -3.2 & 10.1 & 0.002 & 1.10 & & \\
\hline SST median $\left({ }^{\circ} \mathrm{C}\right)$ & & & 4.0 & 0.05 & & & \\
\hline Hard coral (\%) & & & 3.4 & 0.07 & & & \\
\hline Human influence & & & 2.0 & ns & & & \\
\hline SST skewness $\left({ }^{\circ} \mathrm{C}\right)$ & & & 2.0 & $\mathrm{~ns}$ & & & \\
\hline Chlorophyll median $\left(\mathrm{mg} \mathrm{m}^{-3}\right)$ & & & 1.4 & ns & & & \\
\hline SST standard deviation $\left({ }^{\circ} \mathrm{C}\right)$ & & & 1.3 & ns & & & \\
\hline TSS median $\left(\mathrm{g} \mathrm{m}^{-3}\right)$ & & & 0.7 & ns & & & \\
\hline Depth (m) & & & 0.6 & ns & & & \\
\hline SST kurtosis & & & 0.2 & ns & & & \\
\hline Macroalgae (\%) & & & 0.0 & ns & & & \\
\hline
\end{tabular}


to these variables across full gradients were weak and inconsistent, obfuscating any clear and strong correlations. There was some indication of more typically coral-dependent families being associated with higher coral cover in the north while more generalist taxa were more prevalent in the south and with increasing depth. However, these patterns were weak at this family level, which indicates that fish functional roles were broadly distributed, variable between adjacent reefs, and broadly present throughout this region. This suggests that gross ecological function is highly persistent and not easily modified by environmental or habitat changes. This finding does not preclude the possibility of changes of finescale function at lower levels of taxonomic resolution (D'agata et al. 2014, Parravicini et al. 2014)

Fish species and communities responding to factors on a smaller time and space scale than our sampling may explain the weak patterns observed here. For example, fish aggregations at depth could produce the same effects as low fishing in remote or protected areas and not easily distinguished by our snapshot sampling procedure. Many consumers that feed over large areas and even in shallow water at dawn and dusk form temporary aggregations. Consequently, the impacts of these fish are unlikely to be restricted

Table 9. Relationships between environmental variables and fish species richness based on (a) raw number of fish species data and (b) using the residuals from the biomass-number of fish species relationships. Presented are best-fit linear and second order polynomial regression results. The best-fit polynomial also includes the minimum, maximum and midpoints for the polynomial equations. For abbreviations see Table 6 legend

\begin{tabular}{|c|c|c|c|c|c|c|c|}
\hline Term & Model & $\mathrm{p}>F$ & $\mathrm{AICc}$ & $\mathrm{R}^{2}$ & Minimum & Midpoint & Maximum \\
\hline \multicolumn{8}{|c|}{ (a) Number of species per $500 \mathrm{~m}^{2}$} \\
\hline \multirow[t]{2}{*}{ PAR median $\left(\mathrm{E} \mathrm{m}^{-2} \mathrm{~d}^{-1}\right)$} & Linear & 0.0001 & 2390.35 & 0.05 & & & \\
\hline & Polynomial & 0.0002 & 2392.02 & 0.06 & 39.68 & Outside data range & 51.5 \\
\hline \multirow[t]{2}{*}{ TSS median $\left(\mathrm{g} \mathrm{m}^{-3}\right)$} & Linear & 0.08 & 2404.22 & 0.01 & & & \\
\hline & Polynomial & 0.003 & 2397.35 & 0.04 & 0.25 & 1.00 & 2.11 \\
\hline \multirow{2}{*}{ Chlorophyll median $\left(\mathrm{mg} \mathrm{m}^{-3}\right)$} & Linear & 0.001 & 2397.14 & 0.03 & & & \\
\hline & Polynomial & 0.006 & 2399.09 & 0.03 & 0.14 & Outside data range & 1.91 \\
\hline \multirow{2}{*}{ SST median $\left({ }^{\circ} \mathrm{C}\right)$} & Linear & 0.0001 & 2391.84 & 0.05 & & & \\
\hline & Polynomial & 0.0001 & 2384.58 & 0.08 & 26.6 & 27.9 & 29.3 \\
\hline \multirow[t]{2}{*}{ SST standard deviation $\left({ }^{\circ} \mathrm{C}\right)$} & Linear & 0.0001 & 2379.38 & 0.07 & & & \\
\hline & Polynomial & 0.0001 & 2378.50 & 0.08 & 1.44 & 1.59 & 2.29 \\
\hline \multirow[t]{2}{*}{ SST kurtosis } & Linear & ns & 2406.51 & 0.003 & & & \\
\hline & Polynomial & ns & 2407.40 & 0.0001 & & & \\
\hline \multirow[t]{2}{*}{ SST skewness $\left({ }^{\circ} \mathrm{C}\right)$} & Linear & 0.003 & 2398.49 & 0.03 & & & \\
\hline & Polynomial & 0.01 & 2400.24 & 0.03 & -0.26 & Outside data range & 0.21 \\
\hline \multirow[t]{2}{*}{ Human influence } & Linear & 0.008 & 2400.19 & 0.02 & & & \\
\hline & Polynomial & 0.03 & 2402.12 & 0.02 & -2.40 & Outside data range & 5.08 \\
\hline \multicolumn{8}{|c|}{ (b) Residuals of the relationship between fish biomass and number of species } \\
\hline \multirow[t]{2}{*}{ PAR median $\left(\mathrm{E} \mathrm{m}^{-2} \mathrm{~d}^{-1}\right)$} & Linear & 0.0001 & 2205.11 & 0.14 & & & \\
\hline & Polynomial & 0.0001 & 2206.57 & 0.15 & 39.68 & Outside data range & 51.50 \\
\hline \multirow{2}{*}{ TSS median $\left(\mathrm{g} \mathrm{m}^{-3}\right)$} & Linear & 0.07 & 2249.28 & 0.01 & & & \\
\hline & Polynomial & 0.06 & 2248.87 & 0.02 & 0.25 & 1.35 & 2.11 \\
\hline \multirow[t]{2}{*}{ Chlorophyll median $\left(\mathrm{mg} \mathrm{m}^{-3}\right)$} & Linear & 0.04 & 2248.38 & 0.01 & & & \\
\hline & Polynomial & 0.04 & 2247.80 & 0.02 & 0.14 & 1.20 & 1.91 \\
\hline \multirow[t]{2}{*}{ SST median $\left({ }^{\circ} \mathrm{C}\right)$} & Linear & 0.0001 & 2231.95 & 0.07 & & & \\
\hline & Polynomial & 0.0001 & 2230.62 & 0.08 & 26.55 & 28.20 & 29.25 \\
\hline \multirow[t]{2}{*}{ SST standard deviation $\left({ }^{\circ} \mathrm{C}\right)$} & Linear & 0.0001 & 2218.72 & 0.08 & & & \\
\hline & Polynomial & 0.0001 & 2214.71 & 0.10 & 1.44 & 1.64 & 2.29 \\
\hline \multirow[t]{2}{*}{ SST kurtosis } & Linear & ns & 2249.83 & 0.01 & & & \\
\hline & Polynomial & ns & 2251.83 & 0.01 & & & \\
\hline \multirow[t]{2}{*}{ SST skewness $\left({ }^{\circ} \mathrm{C}\right)$} & Linear & ns & 2250.30 & 0.01 & & & \\
\hline & Polynomial & 0.002 & 2242.00 & 0.04 & -0.26 & 0.03 & 0.21 \\
\hline \multirow[t]{2}{*}{ Human influence } & Linear & ns & 2252.07 & 0.001 & & & \\
\hline & Polynomial & ns & 2253.19 & 0.004 & & & \\
\hline
\end{tabular}


to these deep sites. For example, Russ (2003) found large aggregations of reef grazers in the shallow waters of unfished sites in the Great Barrier Reef; a response to the high primary production in shallow reefs. By contrast, high biomass of grazers at depth found in this study may indicate behavioral change to avoid fishing in shallow waters rather than a causative relationship with benthic cover along a depth gradient (Tyler et al. 2009).

\section{Number of species}

The number of species was largely influenced by the biomass of fish communities but other factors related to environment, habitat, and benthic cover contributed to the total variance. The most inclusive stepwise regression models evaluated by AIC stopping rules indicated positive associations with biomass, cover of hard coral, temperature, light, and depth but all variables combined explained only $41 \%$ of the variance. Removing the fish biomass reduced the explained variance to $28 \%$ and the number of significant variables to light and temperature. Consequently, the hard coral cover influence on number of species was likely to be mediated by the biomass of fish rather than reflecting a direct link to coral by itself. Coral is hypothesized to provide more spatial refuge and niches for reef species (Wilson et al. 2009, Kulbicki et al. 2015) but could also just promote the aggregation of fish.

The BIC criteria also removed temperature as a significant factor, which indicates that light is likely to be the main driver influencing number of species, possibly through increasing net benthic production. Many studies suggest that the relationship between productivity and diversity is often unimodal but can also be greatly influenced by disturbance history and competition, especially where production is high (Huston 1994). A meta-analysis of plants by Pärtel et al. (2007) found, however, that the decline in diversity at high ends of production was uncommon in the tropics. This summary's conclusion is consistent with our findings over a limited range of latitudes and productivity. PAR in our study varied from $\sim 40$ to $52 \mathrm{E}$ $\mathrm{m}^{-2} \mathrm{~d}^{-1}$, latitude by $\sim 12^{\circ}$, and the AIC values for the linear model were lower than for the polynomial model. Nevertheless, neither model predicted large amounts of variation in number of species, which suggests a larger role for other factors.

The extent to which species diversity controls versus simply responds to biomass production is a topic of long-running debate in ecology (Huston et al.
2000). These factors are not independent and can interact but the most convincing experimental demonstrations of their interaction are based on sessile organisms that lack movement and aggregating behaviors (Hooper et al. 2005, Cardinale et al. 2009). Some reef fish ecologists, citing literature on plant diversity and ecosystem function have argued that species cause biomass to increase due to more efficient use of resources, particularly at the highest ends of diversity (Mora et al. 2011, 2014, Duffy et al. 2016). Yet, unlike sessile plants, fish are mobile and aggregate for purposes of protection, sex, and feeding; distinguishing between production and aggregation is challenging at the site and snapshot scale. Secondly, the theory of functional diversity and resource use efficiency predicts that the rise in biomass should occur at the low and not the high ends of diversity (Hooper et al. 2005). Consequently, the high variability in fish biomass at high number of species is more likely to result from high variation in biomass where local diversity is near or at a maximum determined by biogeography and habitat. Diversityenhanced production may contribute to a proportion of the biomass but most of the biomass variability should result from variability in aggregating behaviors, codependent relationships, and fishing pressure. Biomass is a metric that integrates a number of community attributes including number of individuals, their sizes and energy use, refuge, and aggregating behavior (Kulbicki et al. 2015, MacNeil \& Connolly 2015). Consequently, all of these aspects of the fish community are likely to have influenced our number of species metric.

Separating the various contributions to diversity is challenging because of fish behaviors and codependencies but also due to the colinearity of potentially predictive variables (Mora \& Robertson 2005). Here, we found colinearity was weak among our many variables. Yet, the comparisons of liberal and strict regression stopping rules made it clear that the strictness of the rules could influence the chosen variables. For example, coral cover was a significant but weak influence and coral could be a proxy for refuge that promotes fish species diversity (Wilson et al. 2009, Kulbicki et al. 2015). However, the statistical methods used here indicated that fish biomass was more influential than hard coral cover. Fish aggregate in areas of moderate to high coral cover but the implication of these findings is that biomass itself is the cause of the diversity not the coral refuge. In support of this contention, a number of studies have found that fish are more resilient to losses of coral cover than expected from correlation analyses (Gra- 
ham et al. 2008, Friedlander et al. 2014, Lamy et al. 2015). This provocative finding indicates the difficulties in evaluating the possible causation, interdependencies, time lags, and feedback in complex ecosystems. Even manipulative experiments will find it difficult to separate affects, as any experimental reduction or addition of coral cover will cause fish to emigrate or immigrate, respectively (Mellin et al. 2016a). Experimentally preventing fish movement would create an artificial refuge from predation, a factor hypothesized to influence the diversity, resulting in an observer- or manipulation-affected experiment.

Soft coral cover was positively but not significantly associated with number of species based on analysis of the raw data but was significantly negatively associated with the residuals of biomass by both AIC and BIC criteria. Consequently, benthic cover plays a small role in influencing diversity but only after removing the effect of the fish biomass. The change from a non-significant positive to significant negative response for raw and residual data, respectively, suggests a complex relationship where the negative association is independent of biomass. Soft coral provides some refuge but should also reduce primary production as benthic space becomes occupied by more heterotrophic and fewer autotrophic taxa. Consequently, refuge provided by soft coral could promote occupation of more species but could also reduce primary production available to support additional taxa.

To complicate interpretations further, a companion study using data from the African coastline indicated that soft corals were positively associated with fish diversity even after accounting for fish biomass (McClanahan 2015a). This indicates that the response for islands is different than for a mainland and this may be associated with how diversity is maintained in these 2 environments. In reviewing diversity, abundance, and body size relationships, Kulbicki et al. (2015) argued that small islands harbor more large-bodied taxa than large islands and therefore larger islands or a mainland will accumulate more of the diversity as small-bodied species. Consequently, soft coral on the mainland would be predicted to support more of these small-bodied taxa per unit of biomass than the islands. If so, this would suggest a provocative reverse response between diversity and soft coral benthic cover in these 2 geographies.

What influences numbers of fish species in this region given the generally weak effects of environmental and benthic cover variables? Island biogeo- graphic dynamics such as the mid-domain, center of origins, or plate tectonics could be influential. Yet, because of the relatively small latitudinal scale of this study $\left(\sim 12^{\circ}\right)$ and the peripheral location of WNME relative to the Indo-Pacific biodiversity center, we did not consider these factors (Connolly et al. 2003). The overlap of species ranges, or mid-domain effect, is likely to be important across large geographies, such as the eastern Pacific or Indo-Pacific (Connolly et al. 2003, Mora \& Robertson 2005) but less influential within the WNME, which is composed of taxa with broad distributions of which WNME is a small portion. Further, a companion paper found that there were only minor declines in site or alpha diversity from the African continent to the offshore islands of the WNME (McClanahan 2015a).

The accumulation of species with biomass have recognizable differences between islands and mainland environments that are influenced by forces of biogeography. For example, the simple biomass-number of species asymptotic model predicted $40 \%$ of the variance in the WNME but explained $58 \%$ of the variance in the African data, which was mostly from coastal locations. Additionally, there were notable differences in the species accumulation rates. For the African coastline, the number of species leveled at biomass values of $\sim 500$ to $600 \mathrm{~kg} \mathrm{ha}^{-1}$ while numbers leveled at biomass values of $>1200 \mathrm{~kg} \mathrm{ha}^{-1}$ in the WNME (Fig. 6). Consequently, there is a slower and less predictable accumulation of species as biomass increases in the WNME compared to the African continent. Because large body sizes will contribute to biomass more than small body sizes, the body size mechanisms described above predict a faster rates of species accumulation per unit biomass on larger than smaller land masses (Kulbicki et al. 2015). This leads to more biomass per unit of diversity on islands, which is what we observe for the African coast and WNME data sets. Because we observe higher biomass at lower levels of diversity on islands, this is further evidence that diversity does not enhance production or biomass unless islands species are more productive and not just larger than mainland taxa. This is unlikely, as net production declines with body size and life span of coral reef fish (McClanahan 2015b). It also suggests that islands in seasonal environments should be susceptible to fishing impacts because larger-bodied taxa make up more of their fauna (Mellin et al. 2016b).

Our study indicates that environmental variables, benthic cover, and even human influence by themselves have variable and small effects on number of species in this WNME region. The strongest factors 


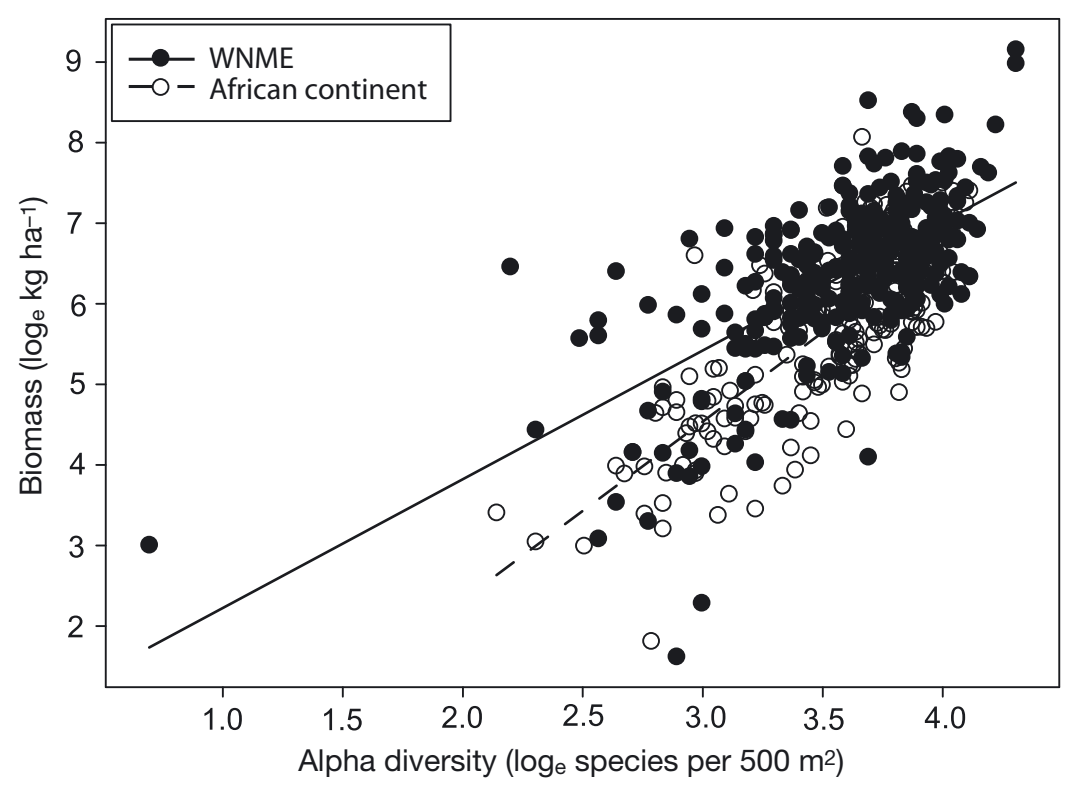

Fig. 6. Relationship between number of species and biomass for data collected from the WNME and data from the east African continent (Kenya, Tanzania, and Mozambique). The original African continental data were presented in McClanahan (2015a) but here is shown omitting the data from the islands

influencing species number were biomass, which had a moderate influence, and light and productivity, which had smaller effects. Given the high spatial and taxonomic variability of the 10 fish communities and weak spatial aggregation of biomass and diversity, it is not surprising that there were no strong gradients and associations with geography and environmental variables. Diversity is largely an attribute of the fish community type and is mostly driven by the biomass of the community. Community stability is likely to be high due to the community's spatial heterogeneity but low due to the island nature and isolation across disturbances (Mellin et al. 2009, 2010, Lamy et al. 2016). Nevertheless, from the perspective of managing this diversity, searching for and protecting or managing small-localized areas of high diversity is not a strategy supported by our field study findings. The slower accumulation of diversity with biomass (and sites) and spatial variability in communities suggests the need to prioritize protection of high biomass through broad spatial scale management that captures between-site more than within-site variation (Ateweberhan \& McClanahan 2016, Mellin et al. 2016a).

\section{Environmental, habitat, and human influences}

Despite evaluating a large number of factors expected to influence fish biomass, many of these were not significant and the predictive power was low even for the significant ones, including depth and benthic cover. There may be other social, economic, and ecological variables that need to be considered and included to explain more of the variance and produce better predictive models. But, it also remains possible that biomass is highly contextual at our scale of study and more variables will add little to improve predictions. Temperature, seawater chlorophyll, water column productivity and other physico-chemical variables have been found to associate with fish biomass in other regions and globally (Nadon et al. 2012, Williams et al. 2015, Cinner et al. 2016, Valdivia et al. 2017). In contrast, we found weak positive associations with depth and soft coral and negative associations with erect algae. Some of the lack of patterns can be due to the scale of metrics we studied. For example, chlorophyll values in the WNME were generally higher $\left(\sim 0.3\right.$ to $\left.1.5 \mathrm{mg} \mathrm{m}^{-3}\right)$ than found in the Pacific Islands ( 0.05 to $0.20 \mathrm{mg}$ $\mathrm{m}^{-3}$ ). Therefore, chlorophyll may not be a limiting factor, nor a good proxy of reef production. Many reports of associations with environmental variables are over larger scales of variation and therefore more influential. Yet, these same variables may loss their statistical predictability when examined across a smaller range or above the levels where the factor is limiting.

Moderate biomass was common throughout the region, notably from Mayotte to northeast Madagascar, which indicates reef fish communities in good ecological condition. Reported biomass values are near or above maximum sustained yield levels where fishing can induce reef degradation (McClanahan et al. 2011). Nevertheless, low fish biomass was observed among reefs in Comoros and near the cities of Hellville and Toliara in Madagascar and Mamoudzou in Mayotte. However, high latitude reefs in southwest Madagascar and Toliara were the only reefs dominated by fleshy macroalgae. Soft corals are frequently associated with poor water quality or low light and deep water (Fabricius 2005). However, soft coral cover was positively associated with PAR and negatively with TSS in this ecoregion, which indicates that soft corals may have replaced hard corals in high light, good water quality and high depth con- 
ditions. This replacement is likely to be promoted by bleaching and mortality of hard corals due to thermal stress (Faure et al. 1984, Maina et al. 2008). Consequently, benthic niches normally occupied by hard corals could be affected by unfavorable climate change and warm water disturbances. If true, reef growth has and will decline with further climate disturbance and ecological change (Perry et al. 2015, McClanahan \& Muthiga 2016).

The relationship between fish biomass and our market-based human influence variable was weak but stronger with depth, which can also act as a refuge from fishing (Tyler et al. 2009). There was a stronger relationship between human influence and valued fisheries target taxa rather than biomass alone. Biomasses in the high human influence areas were composed of taxa of low fisheries or economic value, including small damselfish and odd-shaped piscivores such as lizardfish, cornetfish, scorpionfish, and trumpetfish. Human influence and related variables have been shown to be good predicators of fish biomass and vulnerable taxa in some regions (Brewer et al. 2013, Cinner et al. 2013, Maire et al. 2016, McClanahan et al. 2016) but such variables may be a crude metric of human impacts because of variations in the responses of target and non-target taxa and whether or not fishers are migratory (McClanahan \& Muthiga 2017). The human influence metric does not take account of resource abundance metrics, such as reef area, nor of human infrastructure and travel time, or livelihood alternatives such as agriculture and animal husbandry among other socioeconomic attributes that should influence fishing pressure (Cinner et al. 2016). Given the better predictions of human influence and environmental factors in other regions (Friedlander et al. 2003, Brewer et al. 2013, Houk \& Musburger 2013, Williams et al. 2015, Maire et al. 2016, McClanahan et al. 2016, Mellin et al. 2016a), the weaker responses found here suggests the need for an evaluation of fishing pressure and the factors that promote it at smaller spatial scales. Good models must account for various local factors influencing the balance between fish production and human impacts. We did observe local influences and natural and human variability that were sufficiently high to obscure simple metrics.

Previous well-replicated studies of high compliance fisheries closures in the western Indian Ocean region indicated a maximum biomass of $\sim 1200 \mathrm{~kg}$ $\mathrm{ha}^{-1}$ in fished landscapes (McClanahan \& Graham 2015). Some remote large wilderness areas have higher biomass, $>2000 \mathrm{~kg} \mathrm{ha}^{-1}$, mostly at depth (Gra- ham \& McClanahan 2013, Friedlander et al. 2014). Nevertheless, the most remote areas studied here, such as the Barren and Mitsio Islands, had variable biomass. Barren Islands were lightly fished by seasonally migrating fishers that primarily focus on sharks, but these islands were also impacted by watershed runoff that may reduce reef productivity and biomass, diversity, and change the composition of fish communities (Maina et al. 2013).

Human reliance on reef fish is also expected to depend on rainfall and associated agricultural production. Low rainfall in southwest Madagascar and high rainfall in northern Madagascar is likely to create higher and lower reliance on marine resources in these two regions (Bruggemann et al. 2012). Toliara, the main city in the dry southwest Madagascar region, has a moderate human population of $\sim 160000$, but it is located directly adjacent to one of the region's largest coral reefs and had a fish biomass of $133.6 \pm 58.9 \mathrm{~kg} \mathrm{ha}^{-1}(\mathrm{n}=22)$. In contrast, the 374 $\mathrm{km}^{2}$ island of Mayotte has 120000 people, giving a population density of 570 people $\mathrm{km}^{-2}$ and yet the fish biomass was $890 \pm 216 \mathrm{~kg} \mathrm{ha}^{-1}( \pm 95 \% \mathrm{CI}, \mathrm{n}=$ 17 sites). This is somewhat higher than the whole Madagascar biomass average of $658 \pm 111 \mathrm{~kg} \mathrm{ha}^{-1}$ (n $=312$ ) where the countrywide population density is 35 people $\mathrm{km}^{-2}$ and transport infrastructure is weak. Comoros is a geologically recent volcanic island with poor soils and little reef development on most islands. Environmental conditions in Comoros combined with a population density of 392 people $\mathrm{km}^{-2}$ and weak fisheries management may have led to over exploitation and damaging use of reef resources. Dynamite fishing is reported around the island and fishable biomass was $370 \pm 151 \mathrm{~kg} \mathrm{ha}^{-1}$ but not well sampled ( $\mathrm{n}=8)$.

The poor fit to the human influence metric does not result from a lack of impact of fishing but rather from context-specific responses. Across these broad social-ecological conditions there were likely to be a number of biophysical, infrastructural, cultural, and fisheries management differences that influence the capture of fish (Cinner et al. 2009, 2013). Nevertheless, our findings indicate some of the weaknesses in the development of spatial predictions and models based on distance to market and population sizes that have been used to predict fish biomass (Brewer et al. 2013). For example, a western Indian Ocean fish biomass model based mostly on distance to market and management systems predicted biomass in the Comoros well but underestimated the fishable biomass in Madagascar and Mayotte (McClanahan et al. 2016). On the whole-island scale, the popu- 
lations of Madagascar and Mayotte were underutilizing local fish resources relative to these marketdistance and management system predictions. Consequently, other social-ecological and context conditions are required to improve predictions for these fish resources. In the case of Madagascar, large spatial variability was observed with high impacts in the southwest Madagascar while fish biomasses in the northwest were more aligned with predictions after accounting for other socio-ecological factors (Cinner et al. 2016). More research is needed but fishing may impact portions of Madagascar less than predicted because of social-ecological factors that prevent heavy exploitation.

While poor transport infrastructure for marketing is a likely influence in Madagascar, resulting in less movement of fish to markets, this cannot be the case for Mayotte. Mayotte has good transport infrastructure and trade with the European Union. Consequently, more varied food options, cultural choices, and fisheries management are more likely to explain these disparities. Mayotte has been politically aligned with France (the other Comoros Islands are aligned with Arab nations) and became an Overseas Department of France in 2011. Before Mayotte finalized its governance status change, France proposed that all reefs should be incorporated within a national-scale marine protected area (Legoff 2010). This suggests cultural or economic factors promoted a fisheries management and conservation ethic in Mayotte. Fishable biomass around the other Comoros Islands, on the other hand, fits better to levels predicted by the distance to market-management models developed and tested primarily with east African fish biomass data (McClanahan et al. 2016).

The results here revealed weak spatial structure but indicated the importance of biomass for family representation and therefore functional composition and diversity. This suggests a need to manage for biomass in order to retain these attributes in the fish community for ecosystem-based management. These desired biomass attributes were largely found in fish communities where biomass was $>600 \mathrm{~kg}$ $\mathrm{ha}^{-1}$. These communities were distributed widely throughout the region and, in fact, about $60 \%$ of the study sites fell above this threshold. The $40 \%$ of study sites below this threshold are therefore priorities for increased fisheries restrictions. Clearly, protecting the biomass of fish as opposed to unique locations is a key recommendation for conserving the diversity of fish in the WNME region and possibly more broadly.
Acknowledgements. The Wildlife Conservation Society supported this work through grants from the John D. and Catherine T. MacArthur Foundation, The Tiffany \& Co. Foundation, and the Western Indian Ocean Marine Science Association's Marine Science for Management Program. We are grateful to Bemahfaly Randriamanantsoa who provided fish census data, J. Maina for the satellite data, and M. Azali for assistance with statistics and producing tables and graphs.

\section{LITERATURE CITED}

Ateweberhan M, McClanahan TR (2010) Relationship between historical sea-surface temperature variability and climate change-induced coral mortality in the Western Indian Ocean. Mar Pollut Bull 60:964-970

* Ateweberhan M, McClanahan TR (2016) Partitioning scleractinian coral diversity across reef sites and regions in the Western Indian Ocean. Ecosphere 7:e01243

* Barnes-Mauthe M, Oleson KLL, Zafindrasilivonona B (2013) The total economic value of small-scale fisheries with a characterization of post-landing trends: an application in Madagascar with global relevance. Fish Res 147: 175-185

*Brewer TD, Cinner JE, Green A, Pressey RL (2013) Effects of human population density and proximity to markets on coral reef fishes vulnerable to extinction by fishing. Conserv Biol 27:443-452

* Bruggemann JH, Rodier M, Guillaume MMM, Andréfouët S and others (2012) Wicked social-ecological problems forcing unprecedented change on the latitudinal margins of coral reefs: the case of southwest Madagascar. Ecol Soc 17:47

* Burkepile DE, Hay ME (2008) Herbivore species richness and feeding complementarity affect community structure and function on a coral reef. Proc Natl Acad Sci USA 105: 16201-16206

Burnham KP, Anderson DR (2002) Model selection and inference: a practical information-theoretic approach. Springer, New York, NY

* Cardinale BJ, Bennett DM, Nelson CE, Gross K (2009) Does productivity drive diversity or vice versa? A test of the multivariate productivity-diversity hypothesis in streams. Ecology 90:1227-1241

* Chong-Seng KM, Nash KL, Bellwood DR, Graham NAJ (2014) Macroalgal herbivory on recovering versus degrading coral reefs. Coral Reefs 33:409-419

* Cinner JE, McClanahan TR, Daw TM, Graham NAJ, Maina J, Wilson SK, Hughes TP (2009) Linking social and ecological systems to sustain coral reef fisheries. Curr Biol 19:206-212

Cinner JE, Graham NAJ, Huchery C, MacNeil MA (2013) Global effects of local human population density and distance to markets on the condition of coral reef fisheries. Conserv Biol 27:453-458

Cinner JE, Huchery C, MacNeil MA, Graham NA and others (2016) Bright spots among the world's coral reefs. Nature 535:416-419

Clarke SE, Burnett KM, Miller DJ (2008) Modeling streams and hydrogeomorphic attributes in Oregon from digital and field data. J Am Water Resour Assoc 44:459-477

Connolly SR, Bellwood DR, Hughes TP (2003) Indo Pacific biodiversity of coral reefs: deviations from a mid domain model. Ecology 84:2178-2190

* D'agata S, Mouillot D, Kulbicki M, Andréfouët S and others 
(2014) Human-mediated loss of phylogenetic and functional diversity in coral reef fishes. Curr Biol 24:555-560

Duffy JE, Lefcheck JS, Stuart-Smith RD, Navarrete SA, Edgar GJ (2016) Biodiversity enhances reef fish biomass and resistance to climate change. Proc Natl Acad Sci USA 113:6230-6235

Fabricius KE (2005) Effects of terrestrial runoff on the ecology of corals and coral reefs: review and synthesis. Mar Pollut Bull 50:125-146

Faure G, Guillaume M, Payri C, Thomassin BA, Vanpraet M, Vasseur P (1984) Massive bleaching and death of corals in the Mayotte Reef ecosystem (SW Indian-Ocean). C R Acad Sci Ser III Sci Vie 299:637-642

Friedlander AM, Brown EK, Jokiel PL, Smith WR, Rodgers KS (2003) Effects of habitat, wave exposure, and marine protected area status on coral reef fish assemblages in the Hawaiian archipelago. Coral Reefs 22:291-305

Friedlander AM, Obura D, Aumeeruddy R, Ballesteros E, Church J, Cebrian E, Sala E (2014) Coexistence of low coral cover and high fish biomass at Farquhar Atoll, Seychelles. PLOS ONE 9:e87359

Gabrié C, Vasseur P, Randriamiarana H, Maharavo J, Mara E (2000) The coral reefs of Madagascar. In: McClanahan TR, Sheppard CRC, Obura DO (eds) Coral reefs of the Indian Ocean: their ecology and conservation. Oxford University Press, Oxford, p 411-444

* Graham NAJ, McClanahan TR (2013) The last call for marine wilderness? Bioscience 63:397-402

Graham NAJ, McClanahan TR, MacNeil MA, Wilson SK and others (2008) Climate warming, marine protected areas and the ocean-scale integrity of coral reef ecosystems. PLOS ONE 3:e3039

*Gaham NA, Jennings S, MacNeil MA, Mouillot D, Wilson SK (2015) Predicting climate-driven regime shifts versus rebound potential in coral reefs. Nature 518:94-97

Grove CA, Zinke J, Peeters F, Park W and others (2013) Madagascar corals reveal a multidecadal signature of rainfall and river runoff since 1708. Clim Past 9:641-656

Harris A, Manahira G, Sheppard A, Gough C, Sheppard C (2010) Demise of Madagascar's once great barrier reefchange in coral reef condition over 40 years. Atoll Res Bull 574:16

Hooper DU, Chapin FS, Ewel JJ, Hector A and others (2005) Effects of biodiversity on ecosystem functioning: a consensus of current knowledge. Ecol Monogr 75:3-35

Houk P, Musburger C (2013) Trophic interactions and ecological stability across coral reefs in the Marshall Islands. Mar Ecol Prog Ser 488:23-34

Huston MA (1994) Biological diversity: the coexistence of species on changing landscapes. Cambridge University Press, New York, NY

Huston MA, Aarssen LW, Cade BS, Fridley JD and others (2000) No consistent effect of plant diversity on productivity. Science 289:1255

Jennings S, Grandcourt EM, Polunin NVC (1995) The effects of fishing on the diversity, biomass and trophic structure of Seychelles' reef fish communities. Coral Reefs 14:225-235

Kulbicki M, Parravicini V, Mouillot D (2015) Patterns and processes in reef fish body size. In: Mora C (ed) Ecology of fishes on coral reefs. Cambridge University Press. Cambridge, p 104-115

Lamy T, Legendre P, Chancerelle Y, Siu G, Claudet J (2015) Understanding the spatio-temporal response of coral reef fish communities to natural disturbances: insights from beta-diversity decomposition. PLOS ONE 10:e0138696

* Lamy T, Galzin R, Kulbicki M, Lison de Loma T, Claudet J (2016) Three decades of recurrent declines and recoveries in corals belie ongoing change in fish assemblages. Coral Reefs 35:293-302

* Le Manach F, Gough C, Harris A, Humber F, Harper S, Zeller D (2012) Unreported fishing, hungry people and political turmoil: the recipe for a food security crisis in Madagascar? Mar Policy 36:218-225

Legendre P, Legendre L (1998) Numerical ecology. Developments in environmental modeling, Vol 20. Elsevier, Amsterdam

* Legoff N (2010) La rapide création du parc naturel marin de Mayotte. EchoGéo [On-Line] doi:10.4000/echogeo.11808

MacNeil MA, Connolly SR (2015) Multi-scale patterns and processes in reef fish abundance. In: Mora C (ed) Ecology of fishes on coral reefs. Cambridge University Press, Cambridge, p 116-124

MacNeil MA, Graham NAJ, Cinner JE, Wilson SK and others (2015) Recovery potential of the world's coral reef fishes. Nature 520:341-344

* Maina J, Venus V, McClanahan TR, Ateweberhan M (2008) Modelling susceptibility of coral reefs to environmental stress using remote sensing data and GIS models in the western Indian Ocean. Ecol Model 212:180-199

* Maina J, de Moel H, Zinke J, Madin J, McClanahan TR, Vermaat JE (2013) Human deforestation outweighs future climate change impacts of sedimentation on coral reefs. Nat Commun 4:1986

Maire E, Cinner J, Velez L, Huchery C and others (2016) How accessible are coral reefs to people? A global assessment based on travel time. Ecol Lett 19:351-360

Mansfield ER, Helms BP (1982) Detecting multicollinearity. Am Stat 36:158-160

*McClanahan TR (1997) Effects of fishing and reef structure on East Africa coral reefs. Proc 8th Int Coral Reef Symp 2:1533-1538

*McClanahan TR (2015a) Biogeography versus resource management: How do they compare when prioritizing the management of coral reef fishes in the southwestern Indian Ocean? J Biogeogr 42:2414-2426

McClanahan TR (2015b) Resilience in reef fish communities. In: Mora C (ed) Ecology of fishes on coral reefs. Cambridge University Press, Cambridge, p 183-190

McClanahan TR, Graham NAJ (2015) Marine reserve recovery rates towards a baseline are slower for reef fish community life histories than biomass. Proc Biol Sci 282: 20151938

* McClanahan T, Kaunda-Arara B (1996) Fishery recovery in a coral reef marine park and its effect on the adjacent fishery. Conserv Biol 10:1187-1199

McClanahan TR, Muthiga NA (2016) Similar impacts of fishing and environmental stress on calcifying organisms in Indian Ocean coral reefs. Mar Ecol Prog Ser 560:87-103

McClanahan TR, Muthiga NA (2017) Environmental variability indicates a climate-adaptive center under threat in northern Mozambique coral reefs. Ecosphere 8: e01812

McClanahan TR, Graham NAJ, Maina J, Chabanet P, Bruggemann JH, Polunin NVC (2007) Influence of instantaneous variation on estimates of coral reef fish populations and communities. Mar Ecol Prog Ser 340: 221-234

McClanahan TR, Ateweberhan M, Omukoto J, Pearson L (2009) Recent seawater temperature histories, status, and 
predictions for Madagascar's coral reefs. Mar Ecol Prog Ser 380:117-128

McClanahan TR, Graham NAJ, MacNeil MA, Muthiga NA, Cinner JE, Bruggemann JH, Wilson SK (2011) Critical thresholds and tangible targets for ecosystem-based management of coral reef fisheries. Proc Natl Acad Sci USA 108:17230-17233

McClanahan TR, Graham NAJ, MacNeil MA, Cinner JE (2015) Biomass-based targets and the management of multispecies coral reef fisheries. Conserv Biol 29: 409-417

McClanahan TR, Maina GW, Jones K (2016) Modeling reef fish biomass, recovery potential, and management priorities in the Western Indian Ocean. PLOS ONE 11: $\mathrm{e} 0154585$

Mellin C, Andréfouët S, Kulbicki M, Dalleau M, Vigliola L (2009) Remote sensing and fish-habitat relationships in coral reef ecosystems: review and pathways for multiscale hierarchical research. Mar Pollut Bull 58:11-19

Mellin C, Bradshaw CJA, Meekan MG, Caley MJ (2010) Environmental and spatial predictors of species richness and abundance in coral reef fishes. Glob Ecol Biogeogr 19:212-222

Mellin C, Bradshaw CJA, Fordham DA, Caley MJ (2014) Strong but opposing $\beta$-diversity-stability relationships in coral reef fish communities. Proc Biol Sci 281:20131993

* Mellin C, Aaron MacNeil M, Cheal AJ, Emslie MJ, Julian Caley M (2016a) Marine protected areas increase resilience among coral reef communities. Ecol Lett 19:629-637

Mellin C, Mouillot D, Kulbicki M, McClanahan TR and others (2016b) Humans and seasonal climate variability threaten large-bodied coral reef fish with small ranges. Nat Commun 7:10491

Mora C, Robertson DR (2005) Causes of latitudinal gradients in species richness: a test with fishes of the Tropical Eastern Pacific. Ecology 86:1771-1782

Mora C, Aburto-Oropeza O, Ayala Bocos A, Ayotte PM and others (2011) Global human footprint on the linkage between biodiversity and ecosystem functioning in reef fishes. PLOS Biol 9:e1000606

Mora C, Danovaro R, Loreau M (2014) Alternative hypotheses to explain why biodiversity-ecosystem functioning relationships are concave-up in some natural ecosystems but concave-down in manipulative experiments. Sci Rep 4:5427

Mouillot D, Parravicini V, Bellwood DR, Leprieur F and others (2016) Global marine protected areas do not secure the evolutionary history of tropical corals and fishes. Nat Commun 7:10359

Muthiga NA, Riedmiller S, Carter E, van der Elst R, MannLang J, Horrill C, McClanahan TR (2000) Management status and case studies. In: McClanahan TR, Sheppard CS, Obura D (eds) Coral reefs of the Indian Ocean: their ecology and conservation. Oxford University Press, New York, NY, p 472-507

Nadon MO, Baum JK, Williams ID, Mcpherson JM and others (2012) Re-creating missing population baselines for

Editorial responsibility: Myron Peck, Hamburg, Germany
Pacific reef sharks. Conserv Biol 26:493-503

Newman MJ, Paredes GA, Sala E, Jackson JB (2006) Structure of Caribbean coral reef communities across a large gradient of fish biomass. Ecol Lett 9:1216-1227

* Obura D (2012) The diversity and biogeography of Western Indian Ocean reef-building corals. PLOS ONE 7:e45013

* Parravicini V, Kulbicki M, Bellwood DR, Friedlander AM and others (2013) Global patterns and predictors of tropical reef fish species richness. Ecography 36:1254-1262

* Parravicini V, Villéger S, McClanahan TR, Arias González JE, and others (2014) Global mismatch between species richness and vulnerability of reef fish assemblages. Ecol Lett 17:1101-1110

* Pärtel M, Laanisto L, Zobel M (2007) Contrasting plant productivity-diversity relationships across latitude: the role of evolutionary history. Ecology 88:1091-1097

Pellissier L, Leprieur F, Parravicini V, Cowman PF and others (2014) Quaternary coral reef refugia preserved fish, diversity. Science 344:1016-1019

*Perry CT, Murphy GN, Graham NAJ, Wilson SK, Januchowski-Hartley FA, East HK (2015) Remote coral reefs can sustain high growth potential and may match future sea-level trends. Sci Rep 5:18289

*Plass-Johnson JG, Taylor MH, Husain AA, Teichberg MC, Ferse SC (2016) Non-random variability in functional composition of coral reef fish communities along an environmental gradient. PLOS ONE 11:e0154014

Russ GR (2003) Grazer biomass correlates more strongly with production than with biomass of algal turfs on a coral reef. Coral Reefs 22:63-67

* Spalding MD, Fox HE, Allen GR, Davidson N and others (2007) Marine ecoregions of the world: a bioregionalization of coastal and shelf areas. Bioscience 57:573-583

Thibaut LM, Connolly SR (2013) Understanding diversitystability relationships: towards a unified model of portfolio effects. Ecol Lett 16:140-150

* Tyler EHM, Speight MR, Henderson P, Manica A (2009) Evidence for a depth refuge effect in artisanal coral reef fisheries. Biol Conserv 142:652-667

* Valdivia A, Cox CE, Bruno JF (2017) Predatory fish depletion and recovery potential on Caribbean reefs. Sci Adv 3:e1601303

Vincent IV, Hincksman CM, Tibbetts IR, Harris A (2011) Biomass and abundance of herbivorous fishes on coral reefs off Andavadoaka, Western Madagascar. West Indian Ocean J Mar Sci 10:83-99

*Westneat MW, Alfaro ME, Wainwright PC, Bellwood DR and others (2005) Local phylogenetic divergence and global evolutionary convergence of skull function in reef fishes of the family Labridae. Proc Biol Sci 272:993-1000

Williams ID, Baum JK, Heenan A, Hanson KM, Nadon MO, Brainard RE (2015) Human, oceanographic and habitat drivers of central and western Pacific coral reef fish assemblages. PLOS ONE 10:e0120516

* Wilson SK, Dolman AM, Cheal AJ, Emslie MJ, Pratchett MS, Sweatman HPA (2009) Maintenance of fish diversity on disturbed coral reefs. Coral Reefs 28:3-14

Submitted: November 10, 2016; Accepted: July 20, 2017

Proofs received from author(s): September 20, 2017 